https://doi.org/10.18485/slav_markovic_slobodan.2018.ch24

012 Марковић, С. Ж.

\author{
ЉИљАНА С. ДуКИЋ* \\ Универзитет у Београду \\ Филолошки факултет \\ ВАЛЕНТИНА У. ТАСИЋ ${ }^{* *}$ \\ Универзитет у Београду \\ Филолошки факултет
}

\title{
БИБЛИОГРАФИЈА СЛОБОДАНА Ж. МАРКОВИЋА
}

\section{Ауторске монографије}

1. Лаза Лазаревић / Слободан Ж. Марковић. - Београд : Рад, 1962. - стр. 43.

2. Бранко Ћопић / Слободан Ж. Марковић. - Београд : Рад, 1962. - стр. 43.

3. Милан Ракић / Слободан Ж. Марковић. - Београд : Рад, 1962. - стр. 32.

4. Исидора Секулић / Слободан Ж. Марковић. - Београд : Рад, 1962. - стр. 43.

5. Јован Поповић : живот и књижевно дело / Слободан Ж. Марковић. - Нови Сад : Матица српска, Књижевно одељење, 1968. - 303 стр., [1] лист с таблом ; 25 cm. - Библиографија: стр. 277-294. - Регистар.

6. Književni pokreti i tokovi između dva svetska rata / Slobodan Ž. Marković. - Beograd : Književni klub „Obelisk”, 1970. - 148 str. ; 21 cm. - (Biblioteka Kritike, eseji i studije). - Napomene uz svako poglavlje. - Registar.

7. Zapisi o književnosti za decu / Slobodan Ž. Marković.-1.izd.-Beograd: Interpres, 1970. - 200 str. ; 24 cm. - Registar.

8. Zapisi o književnosti za decu / Slobodan Ž. Marković.-2.izd.-Beograd: Interpres, 1973. - 200 str. ; 24 cm. - (Udžbenici i priručnici ; 1). - Registar.

9. Zapiski o književnosti za otroke / Slobodan Ž. Marković. - Ljubljana : Mladinska knjiga, 1975. - 258 str. ; 20 cm. - (Zbirka Otrok in knjiga ; knj. 4 i 5).

*dljilja.sd@gmail.com

** tasictina@gmail.com 
10. Zapisi o književnosti za decu / Slobodan Ž. Marković. - 3. izd. - Beograd : Naučna knjiga, 1978. - 200 str. ; 24 cm. - (Univerzitetski udžbenici). - Registar.

11. Надреализам / Слободан Марковић. - Горњи Милановац : Дечје новине, 1980. - 42 стр. ; 20 cm. - (Венчева школска библиотека). - Напомене: стр. 44-47.

12. Književne pojave između dva svetska rata / Slobodan Ž. Marković. Valjevo : „Milić Rakić”, 1982. - 199 str. ; 21 cm. - (Biblioteka Posebna izdanja / „Milić Rakić”, Valjevo ; knj. 3)

13. Zapisi o pojavama u književnosti za decu / Slobodan Ž. Marković. Gornji Milanovac : Dečje novine, 1982. - 108 str. ; 24 cm. - Beleška o piscu: str. 105.

14. Записи о књижевности за децу [Брајево писмо] : у четири свеске. Св. 1 / Слободан Ж. Марковић. - Београд : „Филип Вишњић”, 1984. - III, 167 стр. ; $34 \mathrm{~cm}$

15. Записи о књижевности за децу [Брајево писмо] : у четири свеске. Св. 2 / Слободан Ж. Марковић. - Београд : „Филип Вишњић”, 1984. - 161 стр. ; $34 \mathrm{~cm}$

16. Записи о књижевности за децу [Брајево писмо] : у четири свеске. Св. 3 / Слободан Ж. Марковић. - Београд : „Филип Вишњић”, 1984. - II, 161 стр. ; $34 \mathrm{~cm}$

17. Записи о књижевности за децу [Брајево писмо] : у четири свеске. Св. 4 / Слободан Ж. Марковић. - Београд : „Филип Вишњић”, 1984. - 152 стр. ; $34 \mathrm{~cm}$

18. Вук Караџић у књижевном трајању / Слободан Ж. Марковић. Горњи Милановац : Дечје новине ; Приштина : Јединство, 1987 . -214 стр. ; $21 \mathrm{~cm}$

19. Zapisi o književnosti za decu / Slobodan Ž. Marković. -4.izd.-Beograd: Naučna knjiga, 1987. - 200 str. ; 24 cm

20. Континуитети и вредности : студије о новој српској књижевности / Слободан Ж. Марковић. - Ваљево : „Милић Ракић”, 1990. - 318 стр. ; 20 цм. - (Библиотека „Завичајник” ; књ. 3). - Стр. 7-12: Скица за портрет Слободан Ж. Марковића као књижевног историчара / Васо Милинчевић. - Кратка хронологија живота и рада Слободана Ж. Марковића: стр. 315-318.

21. Поезија Десанке Максимовић / Слободан Ж. Марковић. - Београд : Завод за уџбенике и наставна средства, 1990. - 158 стр. ; 18 cm. (Библиотека Портрет књижевног дела. коло 4 ; 1). - Избор из књижевне критике: стр. 122-155. - Хронологија песникињиног живота и рада: стр. 156-[159].

22. Zapisi o književnosti za decu / Slobodan Ž. Marković. -5.izd.-Beograd: Naučna knjiga, 1991. - 200 str. ; 24 cm 
23. Професор у Пекинг, професор из Пекинга / Слободан Ж. Марковић. Ваљево : „Милић Ракић” ; Горњи Милановац : Дечје новине, 1992. - 146 стр. : илустр. ; 21 cm. - (Библиотека „Заједничка издања” ; књ. 16).

24. Књижевно стваралаштво Десанке Максимовић / Слободан Ж. Марковић. - Београд : Чигоја штампа, 1998. - 167 стр. ; 20 cm. - Хронологија живота и рада [Десанке Максимовић]: стр. 159-163. - Белешка о аутору: стр. 165-167.

25. Записи о књижевности за децу III : појаве, жанрови, рецепција / Слободан Ж. Марковић. - Београд : Београдска књига, 2003. - 216 стр. ; 21 cm. - (Библиотека Путеви сазнања ; књ. 1). - ISBN 86-7590-050-3.

26. Српска књижевност између два светска рата : појаве, писци и дела / Слободан Ж. Марковић. - Београд : Друштво за српски језик и књижевност Србије, 2004. - 283 стр. ; 24 cm. - (Библиотека Књижевност и језик ; књ. 4). - Напомене и библиографске референце уз текст. - Поштованом и драгом Милошу Јевтићу срдачно и пријатељски Слободан Ж. Марковић, 20. 02. 2005.: MJ 1806. - ISBN 86-84885-04-X.

27. Појаве, ствараоци и дела у македонској књижевности / Слободан Ж. Марковић. - Београд : Београдска књига, 2005. - 154 стр. ; 20 cm. - (Библиотека Путевима сазнања ; књ. 3). - О овој књизи и аутору: стр. 149-152. - ISBN 86-7590-139-9.

28. Трагање за идеалима / Слободан Ж. Марковић. - Београд : Београдска књига, 2005 (Београд : Беосинг). - 288 стр. ; 20 цм. - (Библиотека Сусретања ; књ. 1). - Стр. 5-7: Духовне вредности као идеал / Ђоко Стојичић. - Поштованом другу Милошу Јевтићу у знак срдачног пријатељства Слободан Ж. Марковић 2005: МJ 1808. ISBN 86-7590-117-8.

29. Припадност књизи : разговори са Слободаном Ж. Марковићем / [разговоре водио] Милош Јевтић. - Београд : Београдска књига, 2006 (Београд : Беосинг). - 138 стр. : фотогр. ; 21 cm. - (Колекција Одговори / [Милош Јевтић] ; књ. 136). - ISBN 86-7590-153-4.

30. Записи о књижевности за децу : писци и дела. 4 / Слободан Ж. Марковић. - Београд : Београдска књига, 2007. - 206 стр. ; 20 cm. - (Библиотека Путеви сазнања / [Београдска књига] ; књ. 5). - Напомене и библиографске референце уз текст. - ISBN 978-86-7590-176-1.

31. Сто година друштва за српски језик и књижевност / Слободан Ж. Марковић ; прилоге приредила Босиљка Милић. - Београд : Друштво за српски језик и књижевност Србије, 2011. - 236 стр. : илустр. ; 23 cm. - Стр. 21-74: Прилог грађи за историју друштва за српскорватски језик и књижевност / Димитрије Вученов. - Напомене и библиографске референце уз текст. - ISBN 978-86-84885-47-2. 


\section{Приређена издања}

32. Изабрана дела / Милован Глишић ; [за штампу приредио Слободан Марковић]. - 1. изд. - Београд : Народна књига, 1958. - 387 стр. ; 20 cm. - (Школска књига). - Књижевни лик Милована Ђ. Глишића / Слободан Ж. Марковић: стр. 5-34. - Савременици о писцу: стр. 351372. - Туђе и мање познате речи: стр. 379-[388]. - Литература.

33. Дружина „Сињи галеб” / Тоне Селишкар ; [превео Милан Ч. Јовановић]. Дружина Пере Квржице / Мато Ловрак ; приредио Слободан Ж. Марковић. - Београд : Нолит, 1960. - 257 стр. ; 17 cm. - (Школска библиотека / Нолит ; 34).

34. Изабрана дела / Милован Глишић ; [за штампу приредио Слободан Марковић]. - 2. изд. - Београд : Народна књига, 1961. - 387 стр. ; 20 cm. - (Школска књига). - Књижевни лик Милована Ђ. Глишића / Слободан Ж. Марковић: стр. 5-34. - Савременици о писцу: стр. 351372. - Туђе и мање познате речи: стр. 379-[388]. - Литература.

35. Приповетке о народноослободилачкој борби / приредио Слободан Ж. Марковић. - Београд : Нолит, 1961. - 167 стр. ; 18 cm. - (Школска библиотека / Нолит ; 37). - Предговор / С. [Слободан] Ж. М. [ Марковић]: стр. 5-6.

36. Вечити младожења : роман / Јаков Игњатовић ; [приредио за штампу Слободан Ж. Марковић]. - Београд : Народна књига, 1962 (Београд : Култура). - 137 стр. ; 21 cm. - (Југословенски класици).

37. Изабрана дела / Јаков Игњатовић ; [приредио за штампу Слободан Ж. Марковић]. - Београд : Народна књига, 1962. - 357 стр. ; 21 cm. - (Школска лектира). - Кор. ств. насл.: Јаков Игњатовић. - Човек и време у књижевном делу Јакова Игњатовића / Слободан Ж. Марковић: стр. 5-15. - Хронологија: стр. 37-339. - Објашњење страних и мање познатих речи: стр. 341-357. - Библиографија.

38. Бранислав Нушић / [избор и редакцију извршио Слободан Ж. Марковић]. - Београд : Завод за издавање уџбеника Социјалистичке Републике Србије, 1965. - 279 стр. ; 20 cm. - (О књижевности : (студије, есеји, критике, чланци) ; 4). - Стр. 7-25: Бранислав Нушић, публика и критика / Слободан Ж. Марковић.

39. Изабрана дела / Јаков Игњатовић ; [приредио Слободан Ж. Марковић]. - 2. изд. - Београд : Народна књига, 1967. - 379 стр. ; 20 cm. - (Југословенски класици / Народна књига). - Књижевно дело Јакова Игњатовића / Слободан Ж. Марковић: стр. 5-15. - Хронологија: стр. 357-360. - Речник туђих и мање познатих речи и имена: стр. 363-[380]. - Библиографија: стр. 361. 
40. Pripovetke / Stjepan Mitrov Ljubiša ... [et al.] ; [izbor i pogovor Slobodan Ž. Marković ; didaktičko-metodička aparatura Petar S. Pešut]. - Beograd : Mlado pokolenje, 1971. - 186 str. ; 19 cm. - (Lektira za VII razred osnovne škole ; knj. 3). - Pogovor: str. 175-180. - Rečnik manje poznatih reči i izraza: str. 181-183.

41. Pripovetke / Stjepan Mitrov Ljubiša,...[et. al.] ; [izbor i pogovor Slobodan Ž. Marković ; didaktičko-metodička aparatura Petar S. Pešut]. - Beograd : Nolit, 1973. - 186 str. ; 20 cm. - (Lektira za VII razred osnovne škole). - Razgovor o pripovetkama: str. 169-174 / P.S.P. Pogovor: str. 175-180 / Slobodan Ž. Marković. - Rečnik manje poznatih reči i izraza: str. 181-183.

42. Ђаку прваку / [избор текстова Слободан Ж. Марковић ; илустрације Босиљка Кићевац ; портрети писаца Бранка Марић]. - Београд : Културно-просветна заједница Србије, 1973. - 95 стр. : илустр., факс. ; 20 cm. - Слике аутора. - Стр. 5-6: Сусрет са школом и књигом / Слободан Ж. Марковић.

Pripovetke / Stjepan Mitrov Ljubiša ... [et al.] ; [izbor i pogovor Slobodan Ž. Marković ; didaktičko-metodička aparatura Petar S. Pešut]. - Beograd : Nolit, 1975. - 221 str. ; 19 cm. - (Lektira za VII razred osnovne škole). - Pogovor: str. 207-215. - Rečnik manje poznatih reči i izraza: str. 217-220. - Didaktički tekst uz svaku pripovetku.

43. Доживљаји Николетине Бурсаћа [Брајево писмо] : у две свеске. Св. 1 / Бранко Ћопић; прир. Слободан Ж. Марковић. - Београд : „Филип Вишњић", 1976. - 146 стр. ; 34 cm. - Према издању из 1971.

44. Доживљаји Николетине Бурсаћа [Брајево писмо] : у две свеске. Св. 2 / Бранко Ћопић; прир. Слободан Ж. Марковић. - Београд : „Филип Вишњић", 1976. - 124 стр. ; 34 cm. - Према издању из 1971. - Стр. 112-119: Поговор о писцу и делу/ Слободан Ж. Марковић. - Речник.

45. Pripovetke / Stjepan Mitrov Ljubiša ... [et al.] ; [izbor i pogovor Slobodan Ž. Marković ; didaktičko-metodička aparatura Petar S. Pešut]. - Beograd : Nolit, 1976. - 218 str. ; 17 cm. - (Lektira za VII razred osnovne škole ; knj. 3). - Razgovor o pripovetkama / P. S. P.: str. 195201. - Pogovor: str. 203-211. - Rečnik manje poznatih reči i izraza: str. 213-216.

46. Поезија љубави и родољубља : изабране песме Алексе Шантића, Милана Ракића, Вељка Петровића, Васка Попе, Бранка Миљковића и Љубомира Симовића / избор и поговор Слободан Ж. Марковић ; илустрације Звонко Грмек. - Београд : Нолит : Просвета : Завод за уџбенике и наставна средства, 1978. - 127 стр. : илустр. ; 18 cm. - (Лектира за VIII разред основне школе ; 1). - Поговор: 
стр. 111-114. - Белешке о песницима: стр. 115-119. - Речник мање познатих речи и израза: стр. 121-123.

47. Приче о партизанима / Бранко Ћопић... [и др.] ; избор и поговор Слободан Марковић ; илустрације Никола Масниковић ; [дидактичко-методички текст Зора Меденица]. - Београд : Нолит : Просвета : Завод за уџбенике и наставна средства, 1978. - 190 стр. : илустр. ; 18 cm. - (Лектира за III разред основне школе ; 4). - Разговор о причама: стр. 171-175. - Поговор: стр. 177-186. - Речник мање познатих речи и израза: стр. 187-188.

48. Има једна земља : изабране народне песме и песме Бранка Ћопића, Звонимира Балога, Славка Јаневског, Михала Бабинке, Реџепа Хоџе и Бранислава Л. Лазаревића / избор и поговор Слободан Ж. Марковић ; илустрације Александар Хецл ; [дидактичко-методички текст Зора Меденица]. - [3. изд.]. - Београд : Нолит : Просвета : Завод за уџбенике и наставна средства, 1979. - 76 стр. : илустр. ; 18 cm. - (Лектира за II разред основне школе ; 1). - Стр. 67-70: Разговор о песмама / Зора Меденица. - Стр. 71-73: Поговор / Слободан Ж. Марковић. - Речник мање познатих речи и израза: стр. 74.

49. Има једна земља : изабране народне песме и песме Бранка Ћопића, Звонимира Балога, Славка Јаневског, Михала Бабинке, Реџепа Хоџе и Бранислава Л. Лазаревића / избор и поговор Слободан Ж. Марковић ; илустрације Александар Хецл ; [дидактичко-методички текст Зора Меденица]. - [4. изд.]. - Београд : Нолит : Просвета : Завод за уџбенике и наставна средства, 1979. - 76 стр. : илустр. ; 18 cm. - (Лектира за II разред основне школе ; 1). - Стр. 67-70: Разговор о песмама / Зора Меденица. - Стр. 71-73: Поговор / Слободан Ж. Марковић. - Речник мање познатих речи и израза: стр. 74.

50. Има једна земља [Брајево писмо] : изабране народне песме и песме Бранка Ћопића, Звонимира Балога, Славка Јаневског, Михала Бабинке, Реџепа Хоџе и Бранислава Л. Лазаревића : лектира за Ии разред основне школе / избор и поговор Слободан Ж. Марковић. - Београд : „Филип Вишњић”, 1979. - 61 стр. ; 32 cm. - Према издању из 1978.

51. Приче о партизанима / Бранко Ћопић...[и др.] ; избор и поговор Слободан Ж. Марковић ; илустрације Никола Масниковић ; [дидактичко-методички текст Зора Меденица]. - [3. изд.]. - Београд : Нолит : Просвета : Завод за уџбенике и наставна средства, 1979 (Београд : Београдски издавачко-графички завод). - 190 стр. : илустр. ; $18 \mathrm{~cm}$. - (Лектира за III разред основне школе ; 4). - Разговор о причама: стр. 171-175. - Поговор: стр. 177-186. - Речник мање познатих речи и израза: стр. 187-188. 
52. Приче о партизанима / Бранко Ћопић...[и др.] ; избор и поговор Слободан Ж. Марковић ; илустрације Никола Масниковић ; [дидактичко-методички текст Зора Меденица]. - 2. изд. - Београд : Нолит : Просвета : Завод за уџбенике и наставна средства, 1979. - 190 стр. :илустр. ; 18 cm. - (Лектира за III разред основне школе ; 4). - Разговор о причама: стр. 171-175. - Поговор: стр. 177-186. - Речник мање познатих речи и израза: стр. 187-188.

53. Приче о партизанима [Брајево писмо] : у две свеске. Св. 1 / Бранко Ћопић...[и др.] ; избор и поговор Слободан Марковић. - Београд : „Филип Вишњић”, 1979. - III, 116 стр. ; 34 cm. - Према издању из 1979. - Речник.

54. Приче о партизанима [Брајево писмо] : у две свеске. Св. 2 / Бранко Ћопић... [и др.] ; избор и поговор Слободан Марковић. - Београд : „Филип Вишњић”, 1979. - 76 стр. ; 34 cm. - Према издању из 1979. - Речник. - Стр. 62-73: Поговор / Слободан Ж. Марковић.

55. Сусрети [Брајево писмо] : изабране народне приче и приче Десанке Максимовић, Еле Пероци, Нандора Мајора, Јураја Тушјака и Лазе Лазића / избор и поговор Слободан Ж. Марковић. - Београд : „Филип Вишњић", 1979. - 80 стр. ; 34 cm. - Према издању из 1978. - Стр. 77-79: Поговор: Слободан Ж. Марковић. - Речник.

56. Има једна земља : изабране народне песме и песме Бранка Ћопића, Звонимира Балога, Славка Јаневског, Михала Бабинке, Реџепа Хоџе и Бранислава Л. Лазаревића / избор и поговор Слободан Ж. Марковић ; илустрације Александар Хецл ; [дидактичко-методички текст Зора Меденица]. - 5 изд. - Београд : Нолит : Просвета : Завод за уџбенике и наставна средства, 1980. - 76 стр. : илустр. ; $18 \mathrm{~cm}$. - (Лектира за II разред основне школе ; 1). - Разговор о песмама: стр. 67-69. - Стр. 71-73: Поговор / Слободан Ж. Марковић. - Речник мање познатих речи и израза: стр. 74.

57. Књига о искованој срећи : избор поезије, прозе и критике / Јован Поповић ; [припремио Слободан Ж. Марковић]. - Сремска Митровица : Сремске новине, 1980. - 223 стр. : илустр. ; 21 cm. - Ангажованост књижевног дела Јована Поповића / Слободан Ж. Марковић: стр. 5-18.

58. Поезија љубави и родољубља : изабране песме Алексе Шантића, Милана Ракића, Вељка Петровића, Васка Попе, Бранка Миљковића и Љубомира Симовића / избор и поговор Слободан Ж. Марковић ; илустрације Звонко Грмек. - [2. изд.]. - Београд : Нолит : Просвета : Завод за уџбенике и наставна средства, 1980. - 127 стр. : илустр. ; 19 cm. - (Лектира за VIII разред основне школе ; 1). - Поговор: стр. 111-114. - Белешке о песницима: стр. 115-119. - Речник мање познатих речи и израза: стр. 121-123. 
59. Приповетке / Стјепан Митров Љубиша ... [и др.] ; избор и поговор Слободан Ж. Марковић ; илустрације Мирјана Мартиновић ; [дидактичко-методички текст Веселка Бањац]. - [2. изд.]. - Београд : Нолит : Просвета : Завод за уџбенике и наставна средства, 1980. 135 стр. : илустр. ; 18 cm. - (Лектира за VII разред основне школе ; 7). - Разговор о приповеткама: стр. 117-120. - Поговор: стр. 121128. - Речник мање познатих речи и израза: стр. 129-133.

60. Приче о партизанима / Бранко Ћопић ... [и др.] ; избор и поговор Слободан Ж. Марковић ; илустрације Никола Масниковић ; [дидактичко-методички текст Зора Меденица]. - [4. изд.]. - Београд : Нолит : Просвета : Завод за уџбенике и наставна средства, 1980. - 190 стр. : илустр. ; $18 \mathrm{~cm}$. - (Лектира за III разред основне школе ; 4). -Разговор о причама: стр. 171-175. - Поговор: стр. 177-186. - Речник мање познатих речи и израза: стр. 187-188.

61. Приче о партизанима / Бранко Ћопић ... [и др.] ; избор и поговор Слободан Ж. Марковић ; илустрације Никола Масниковић ; [дидактичко-методички текст Зора Меденица]. - 5. изд. - Београд : Нолит : Просвета : Завод за уџбенике и наставна средства, 1980. - 190 стр. : илустр. ; 18 cm. - (Лектира за III разред основне школе ; 4). - Разговор о причама: стр. 171-175. - Поговор: стр. 177-186. - Речник мање познатих речи и израза: стр. 187-188.

62. Има једна земља : изабране народне песме и песме Бранка Ћопића, Звонимира Балога, Славка Јаневског, Михала Бабинке, Реџепа Хоџе и Бранислава Л. Лазаревића / избор и поговор Слободан Ж. Марковић ; илустрације Александар Хецл ; [дидактичко-методички текст Зора Меденица]. - [6. изд.]. - Београд : Нолит : Просвета : Завод за уџбенике и наставна средства, 1981. - 76 стр. : илустр. ; 18 cm. - (Лектира за II разред основне школе ; 1). - Разговор о песмама: стр. 67-69. - Поговор: стр. 71-73. - Речник мање познатих речи и израза: стр. 74.

63. Поезија љубави и родољубља : изабране песме Алексе Шантића, Милана Ракића, Вељка Петровића, Васка Попе, Бранка Миљковића и Љубомира Симовића / избор и поговор Слободан Ж. Марковић ; илустрације Звонко Грмек. - [3. изд.]. - Београд : Нолит : Просвета : Завод за уџбенике и наставна средства, 1981. - 127 стр. : илустр. ; $18 \mathrm{~cm}$. - (Лектира за VIII разред основне школе ; 1). - Поговор: стр. 111-114. - Белешке о песницима: стр. 115-119. - Речник мање познатих речи и израза: стр. 121-123.

64. Приповетке / Стјепан Митров Љубиша, Фран Левстик, Милован Глишић, Лаза Лазаревић, Вјенцеслав Новак, Јосип Козарац ; избор и поговор Слободан Ж. Марковић ; илустрације Мирјана Марти- 
новић ; [дидактичко-методички текст Веселка Бањац]. - [3. изд.]. - Београд : Нолит : Просвета : Завод за уџбенике и наставна средства, 1981. - 135 стр. : илустр. ; $18 \mathrm{~cm}$. - (Лектира за VII разред основне школе ; 7). - Разговор о приповеткама: стр. 117-120. - Поговор: стр. 121-128. - Речник мање познатих речи и израза: стр. 129-133.

65. Приче о партизанима / Бранко Ћопић ... [и др.] ; избор и поговор Слободан Ж. Марковић ; илустрације Никола Масниковић ; [дидактичко-методички текст Зора Меденица]. - 6. изд. - Београд : Нолит : Просвета : Завод за уџбенике и наставна средства, 1981. - 190 стр. : илустр. ; 19 cm. - (Лектира за III разред основне школе ; 4). - Разговор о причама: стр. 171-175. - Поговор: стр. 177-186. - Речник мање познатих речи и израза: стр. 187-188.

66. Сусрети : изабране народне приче и приче Десанке Максимовић, Еле Пероци, Нандора Мајора, Јураја Тушјака и Лазе Лазића / избор и поговор Слободан Ж. Марковић ; илустрације Александар Хецл ; [дидактичко-методички текст Зора Меденица]. - [6. изд.]. - Београд : Нолит : Просвета : Завод за уџбенике и наставна средства, 1981. - 83 стр. : илустр. ; 18 cm. - (Лектира за II разред основне школе ; 2). - Разговор о причама: стр. 75-78. - Поговор: стр. 79-80. - Речник мање познатих речи: стр. 81.

67. Има једна земља : изабране народне песме и песме Бранка Ћопића...[и др.] / избор и поговор Слободан Ж. Марковић ; илустрације Александар Хецл ; [дидактичко-методички текст Зора Меденица]. - [7. изд.]. - Београд : Нолит : Просвета : Завод за уџбенике и наставна средства, 1982. - 76 стр. : илустр. ; $18 \mathrm{~cm}$. - (Лектира за II разред основне школе ; 1). - Разговор о песмама : стр. 67-69. - Поговор: стр. 71-73. - Речник мање познатих речи и израза: стр. 74.

68. Приповетке / Стјепан Митров Љубиша ... [и др.] ; избор и поговор Слободан Ж. Марковић ; илустрације Мирјана Мартиновић ; дидактичко-методички текст Веселка Бањац. - [4. изд.]. - Београд : Нолит : Просвета : Завод за уџбенике и наставна средства, 1982. - 135 стр. : илустр. ; $18 \mathrm{~cm}$. - (Лектира за VII разред основне школе ; 7). - Разговор о приповеткама: стр. 117-120. - Поговор: стр. 121-128. Речник мање познатих речи и израза: стр. 129-133.

69. Приче о партизанима / Бранко Ћопић ... [и др.] ; избор и поговор Слободан Ж. Марковић ; илустрације Никола Масниковић. - [7. изд.]. - Београд : Нолит : Просвета : Завод за уџбенике и наставна средства, 1982. - 190 стр. : илустр. ; 18 cm. - (Лектира за III разред основне школе ; 4). - Поговор: стр. 177-186. 
70. Сусрети : изабране народне приче и приче Десанке Максимовић...[и др.] / избор и поговор Слободан Ж. Марковић ; илустрације Александар Хецл ; [дидактичко-методички текст Зора Меденица]. - [7. изд.]. - Београд : Нолит : Просвета : Завод за уџбенике и наставна средства, 1982. - 83 стр. : илустр. ; 18 cm. - (Лектира за II разред основне школе ; 2). - Разговор о причама : стр. 75-78. - Поговор: стр. 79-80. - Речник и мање познатих речи: стр. 81.

71. Има једна земља : изабране народне песме и песме Бранка Ћопића, Звонимира Балога, Славка Јаневског, Михала Бабинке, Реџепа Хоџе и Бранислава Л. Лазаревића / избор и поговор Слободан Ж. Марковић ; илустрације Александар Хецл ; [дидактичко-методички текст Зора Меденица]. - [8. изд.]. - Београд : Нолит : Просвета : Завод за уџбенике и наставна средства, 1983. - 76 стр. : илустр. ; 18 cm. - (Лектира за II разред основне школе ; 1). - Разговор о песмама: стр. 67-69. - Поговор: стр. 71-73. - Речник мање познатих речи и израза: стр. 74.

72. Истините легенде / Јован Поповић ; [избор, предговор методички текст и биљешка о писцу Слободан Ж. Марковић]. - Сарајево : „Веселин Маслеша", 1983. - 143 стр. ; 20 cm. - (Библиотека Ластавица : лектира). - „Истините легенде”- запис о човјеку у рату: стр. 5-9. - Стр. 133-137: Објашњења и рјечник мање познатих ријечи и појмова / С. М. - Разговор о Истинитим легендама: стр. 139-140. Биљешка о писцу: стр. 141-142.

73. Поезија љубави и родољубља : изабране песме Алексе Шантића, Милана Ракића, Вељка Петровића, Васка Попе, Бранка Миљковића и Љубомира Симовића / избор и поговор Слободан Ж. Марковић ; илустрације Звонко Грмек. - [4. изд.]. - Београд : Нолит : Просвета : Завод за уџбенике и наставна средства, 1983. - 127 стр. : илустр. ; $18 \mathrm{~cm}$. - (Лектира за VIII разред основне школе ; 1). - Поговор: стр. 111-114. - Белешке о песницима: стр. 115-119. - Речник мање познатих речи и израза: стр. 121-123.

74. Приче о партизанима / Бранко Ћопић ...[и др.] ; избор и поговор Слободан Ж. Марковић ; илустрације Никола Масниковић ; [дидактичко-методички текст Зора Меденица]. - [8. изд.]. - Београд : Нолит : Просвета : Завод за уџбенике и наставна средства, 1983. - 190 стр. : илустр. ; $18 \mathrm{~cm}$. - (Лектира за III разред основне школе ; 4). - Разговор о причама: стр. 171-175. - Поговор: стр. 177-186. - Речник мање познатих речи и израза: стр. 187-188.

75. Сусрети : изабране народне приче и приче Десанке Максимовић , Еле Пероци, Нандора Мајора, Јураја Тушјака и Лазе Лазића / избор и поговор Слободан Ж. Марковић ; илустрације Александар Хецл ; 
[дидактичко-методички текст Зора Меденица]. - [8. изд.]. - Београд : Нолит : Просвета : Завод за уџбенике и наставна средства, 1983. - 83 стр. : илустр. ; $18 \mathrm{~cm}$. - (Лектира за II разред основне школе ; 2). - Разговор о причама: стр. 75-78. - Поговор: стр. 79-80. - Речник мање познатих речи: стр. 81.

76. Sledovi revolucije v umetnosti za otroke in mladino : zbornik sestavkov strokovnih posvetovanj Festivala Kurirček o umetniški ustvarjalnosti za otroke in mladino s tematiko iz NOB in revolucije na področju književne, likovne in glasbene umetnosti / [uredili Slobodan Ž. Marković ... [et al.] ; prevedli iz srbohrvaščine Teodor Lorenčič in Iztok Ilich, iz makedonščine Nada Carevska]. - Ljubljana : Partizanska knjiga, 1983. - 182 str., [16] str. s tablama (ilustr.) ; 24 cm. - Na koricama podnasl.: 20 let Festivala Kurirček. - Registar.

77. Антологија српске приче за децу / [приредио] Слободан Ж. Марковић. - Београд : Српска књижевна задруга, 1984. - 345 стр. ; $21 \mathrm{~cm}$ - (Антологије / Српска књижевна задруга). - Стр. 335-340: Поговор / Слободан Ж. Марковић. - Писци и дела: стр. 329-334.

78. Има једна земља : изабране народне песме и песме Бранка Ћопића, Звонимира Балога, Славка Јаневског, Михала Бабинке, Реџепа Хоџе и Бранислава Л. Лазаревића / избор и поговор Слободан Ж. Марковић ; илустрације Александар Хецл ; [дидактичко-методички текст Зора Меденица]. - [9. изд.]. - Београд : Нолит : Просвета : Завод за уџбенике и наставна средства, 1984. - 76 стр. : илустр. ; 18 cm. - (Лектира за II razred osnovne škole ; 1). - Разговор о песмама: стр. 67-69. - Поговор: стр. 71-73. - Речник мање познатих речи и израза стр. 74.

79. Приповетке / Стјепан Митров Љубиша ... [и др.] ; избор и поговор Слободан Ж. Марковић ; илустрације Мирјана Мартиновић ; [дидактичко-методички текст Веселка Бањац]. - 5. изд. - Београд : Нолит : Просвета : Завод за уџбенике и наставна средства, 1984. - 135 стр. : илустр. ; $18 \mathrm{~cm}$. - (Лектира за VII разред основне школе ; 7). - Разговор о приповеткама: стр. 117-120. - Поговор: стр. 121-128. - Речник мање познатих речи и израза: стр. 129-133.

80. Приче о партизанима / Бранко Ћопић...[и др.] ; избор и поговор Слободан Ж. Марковић ; илустрације Никола Масниковић ; [дидактичко-методички текст Зора Меденица]. - [9. изд.]. - Београд : Нолит : Просвета : Завод за уџбенике и наставна средства, 1984. - 190 стр. : илустр. ; $18 \mathrm{~cm}$. - (Лектира за III разред основне школе ; 4). - Разговор о причама: стр. 171-175. - Поговор: стр. 177-186. - Речник мање познатих речи и израза: стр. 187-188. 
81. Сусрети : изабране народне приче и приче Десанке Максимовић, Еле Пероци, Нандора Мајора, Јураја Тушјака и Лазе Лазића / избор и поговор Слободан Ж. Марковић ; илустрације Александар Хецл ; [дидактичко-методички текст Зора Меденица]. - [9. изд.]. - Београд : Нолит : Просвета : Завод за уџбенике и наставна средства, 1984. - 83 стр. : илустр. ; 18 cm. - (Лектира за II разред основне школе ; 2). - Разговор о причама: стр. 75-78. - Поговор: стр. 79-80. - Речник мање познатих речи: стр. 81.

82. Поезија љубави и родољубља : изабране песме Алексе Шантића, Милана Ракића, Вељка Петровића, Васка Попе, Бранка Миљковића и Љубомира Симовића / избор и поговор Слободан Ж. Марковић ; илустрације Звонко Грмек. - [5. изд.]. - Београд : Нолит : Просвета : Завод за уџбенике и наставна средства, 1985. - 127 стр. : илустр ; $18 \mathrm{~cm}$. - (Лектира за VIII разред основне школе ; 1). - Поговор: стр. 111-114. - Белешке о песницима: стр. 115-119. - Речник мање познатих речи и израза: стр. 121-123.

83. Из савремене југословенске поезије за децу / избор и поговор Слободан Ж. Марковић ; дидактичко-методички текст Зора Меденица ; илустрације Александар Хецл. - Београд : Нолит, 1986. - 62 стр. : илустр.у боји ; 18 cm. - (Лектира за II разред основне школе ; 3). - Разговор о песмама: стр. 55-57. - Поговор: стр. 58-59. - Речник мање познатих речи и израза: стр. 60.

84. Антологија српске приче за децу / [приредио] Слободан Ж. Марковић. - 2. изд. [фототипско]. - Београд : Српска књижевна задруга, 1987. - 345 стр. ; 21 cm. - (Антологије). - Писци и дела: стр. 329334. - Поговор / Слободан Ж. Марковић: стр. 325-340.

85. Дјечак прати змаја / Бранко Ћопић ; избор и поговор Слободан Ж. Марковић. - [3. изд.]. - Београд : Нолит, 1987. - 168 стр. ; 18 cm. (Лектира за VII разред основне школе ; 3). - Поговор: стр. 163-166. - Речник мање познатих речи: стр. 167.

86. Из савремене југословенске поезије за децу / избор и поговор Слободан Ж. Марковић ; дидактичко-методички текст Зора Меденица ; илустрације Александар Хецл . - 2. изд. - Београд : Нолит, 1987. - 62 стр. : илустр. ; 18 cm. - (Лектира за II разред основне школе ; 3). - Разговор о песмама: стр. 55-57. - Поговор: стр. 58-59.

87. Истините легенде / Јован Поповић ; избор и поговор Слободан Марковић ; дидактичко-методички текст Веселка Бањац. - [2. изд.]. - Београд : Нолит, 1987. - 167 стр. ; 18 cm. - (Лектира за VI разред основне школе ; 8). - Разговор о причама: стр. 156-158. - Поговор: стр. 159-162. - Речник мање познатих речи и објашњења: стр. 163-167. 
88. Istinite legende / Jovan Popović ; [izbor, predgovor, metodički tekst i bilješke o piscu Slobodan Ž. Marković]. - [2. izd.]. - Sarajevo : „Veselin Masleša", 1987. - 143 str. ; 20 cm. - (Lastavica. Lektira). - „Istinite legende" - zapis o čovjeku u ratu: str. 5-9.

89. Дјечак прати змаја / Бранко Ћопић ; избор и поговор Слободан Ж. Марковић. - [2. изд.]. - Београд : Нолит, 1988. - 168 стр. ; 18 cm. - (Лектира за VII разред основне школе ; 3). - Поговор: стр. 163166. - Речник мање познатих речи: стр. 167.

90. Звездана светковина / Десанка Максимовић ; [избор, предговор и поговор Слободан Ж. Марковић]. - Ваљево : „Милић Ракић”, 1988. - 256 стр. ; 20 cm. - (Библиотека „Завичајник” ; књ. 4). - Песник и поезија, завичај и живот: стр. 7-30.

91. Из савремене југословенске поезије за децу / избор и поговор Слободан Ж. Марковић ; дидактичко-методички текст Зора Меденица ; илустрације Александар Хецл . - [3. изд.]. - Београд : Нолит, 1988. - 62 стр. : илустр. у бојама ; $18 \mathrm{~cm}$. - (Лектира за II разред основне школе ; 3). - Разговор о песмама: стр. 55-57. - Поговор: стр. 58-59. - Речник мање познатих речи: стр. 62.

92. Истините легенде / Јован Поповић ; избор и поговор Слободан Марковић ; дидактичко-методички текст Веселка Бањац. - [3. изд.]. - Београд : Нолит, 1988. - 167 стр. ; 18 цм. - (Лектира за VI разред основне школе ; 8). - Разговор о причама: стр. 156-158 ; Поговор: стр. 159-162. - Речник мање познатих речи и објашњења: стр. 163167.

93. Ко је бољи јунак : изабране песме и приче / Јован Јовановић-Змај ; избор и поговор Слободан Ж. Марковић ; [илустрације Јеврем Милановић]. - Београд : Српска књижевна задруга, 1988. - 217 стр. : илустр. ; 22 cm. - (Књига за децу и одрасле ; 22). - Поетски лик детета у Змајевим песмама за децу: стр. 209-215.

94. Дјечак прати змаја / Бранко Ћопић ; избор и поговор Слободан Ж. Марковић. - [3. изд.]. - Београд : Нолит, 1989. - 168 стр. ; $18 \mathrm{~cm}$. (Лектира за VII разред основне школе ; 3). - Поговор: стр. 163-166. - Речник мање познатих речи: стр. 167.

95. Антологија српске приче за децу / [приредио] Слободан Ж. Марковић. - 3. [фототипско] изд. - Београд : Српска књижевна задруга, 1990. - 345 стр. ; 21 cm. - (Антологије / Српска књижевна задруга). - Писци и дела: стр. 329-334. - Стр. 335-340: Поговор / Слободан Ж. Марковић.

96. Дјечак прати змаја / Бранко Ћопић ; избор и поговор Слободан Ж. Марковић. - 4. изд. - Београд : Нолит, 1990. - 168 стр. ; 18 cm. - 
(Лектира за VII разред основне школе ; 3). - Поговор: стр. 163-166. - Речник мање познатих речи: стр. 167.

97. Истините легенде / Јован Поповић ; избор и поговор Слободан [Ж.] Марковић ; дидактичко-методички текст Веселка Бањац. - [5. изд.]. - Београд : Нолит, 1990. - 167 стр. ; 18 cm. - (Лектира за VI разред основне школе ; 8). - Разговор о причама: стр. 156-158. - Поговор: стр. 159-162. - Речник мање познатих речи и објашњења: стр. 163-167.

98. Антологија српске приче за децу / [приредио] Слободан Ж. Марковић . - 4. [фототипско] изд. - Београд : Српска књижевна задруга, 1991. - 345 стр. ; 21 cm. - (Антологије / Српска књижевна задруга). - Писци и дела: стр. 329-334. - Поговор / Слободан Ж. Марковић: стр. 335-340. - Напомена издавача: стр. 341. - Фототипско изд. из 1984.

99. Из савремене југословенске поезије за децу / избор и поговор Слободан Ж. Марковић ; дидактичко-методички текст Зора Меденица ; илустрације Александар Хецел. - Београд : Нолит, 1991. - 62 стр. : илустр. ; 18 цм. - (Лектира за II разред основне школе ; 3). - Разговор о песмама: стр. 55-57. - Стр. 58-59: Поговор / Слободан Ж. Марковић.

100. Антологија српске приче за децу / [приредио] Слободан Ж. Марковић . - 5., [фототипско] изд. - Београд : Српска књижевна задруга, 1992. - 345 стр. ; 20 cm. - (Антологије / Српска књижевна задруга). - „Штампано о стогодишњици Српске књижевне задруге”--> насл. стр. - Тираж 3.000. - Писци и дела: стр. 329-334. - Стр. 335-340: Поговор / Слободан Ж. Марковић.

101. Рађање љубави ; Тражим помиловање / Десанка Максимовић ; предговор, животопис и избор песама Слободан Ж. Марковић. - Београд : Просвета, 1992. - 185 стр. ; 18 цм. - (Школска лектира / Просвета). - Летопис поезије и песничка мисија Десанке Максимовић: стр. 7-17. - Хронологија: стр. 171-176.

102. Антологија српске приче за децу / [приредио] Слободан Ж. Марковић . - 6. фототипско изд.. - Београд : Српска књижевна задруга, 1994. - 345 стр. ; 20 cm. - (Антологије / Српска књижевна задруга). - Писци и дела: стр. 329-334. - Стр. 335-340: Поговор / Слободан Ж. Марковић.

103. Грађење гнезда / Десанка Максимовић ; избор и поговор Слободан Ж. Марковић. - Горњи Милановац : Дечје новине, 1994. - 166 стр. : илустр. ; 24 cm. - (Библиотека Златни лептир ; св. 1). -Ауторова слика. - Дарови деци Десанке Максимовић: стр. 159-163. 
104. Ђаку прваку ; приредио Слободан Ж. Марковић ; [цртежи ликова писаца Градимир Смуђа]. - Београд : Просвета, 1994. - 167 стр. : илустр. ; $23 \mathrm{~cm}$. - Портрети аутора. - Стр. 7-9: Сусрет са школом и књигом / Слободан Ж. Марковић.

105. Антологија српске приче за децу / [приредио] Слободан Ж. Марковић. - 6. [фототипско] изд. - Београд : Српска књижевна задруга, 1995. - 345 стр. ; 21 cm. - (Антологије / Српска књижевна задруга). - Писци и дела: стр. 329-334. - Поговор / Слободан Ж. Марковић: стр. 335-340. - Напомена издавача: стр. 341. - Фототипско изд. из 1984.

106. Весник : песме деце песника. Књ. 1 / [песме изабрали Драган Лукић, Воја Марјановић, Слободан Ж. Марковић]. - Београд : Lingva, 1995. - 203 стр. ; 17 cm. - (Библиотека „Песнички подмладак”). - Стр. 5-8: Весник - будући песници / Воја Марјановић. - Стр. 199: Поговор / В. М. [Воја Марјановић].

107. Десанка Максимовић у свом књижевном времену : зборник радова / Десанкини мајски разговори 15. и 16. маја 1995., Београд, Ваљево, Бранковина ; [приређивач Слободан Ж. Марковић]. - Београд : Задужбина Десанка Максимовић, 1995. - 164 стр. ; $21 \mathrm{~cm}$

108. За мамине очи / Мира Алечковић ; избор и поговор Слободан Ж. Марковић. - Горњи Милановац : Дечје новине, 1995. - 156 стр. : илустр. ; 24 cm. - (Библиотека Златни лептир ; св. 2). - Стр. 143151: Топлина материнства и родољубља Мире Алечковић / Слободан Ж. Марковић.

109. Поезија Љубомира Симовића : зборник радова, поводом књиге Учење у мраку / [приређивач Слободан Ж. Марковић]. - Београд : Задужбина Десанка Максимовић, 1995. - 64 стр. ; 21 cm. - (Десанкини мајски разговори)

110. Чудесан свет / Десанка Максимовић ; избор и предговор Слободан Ж. Марковић. - Нови Сад : Прометеј, 1995. - 152 стр. ; $21 \mathrm{~cm}$. - (Библиотека Читалачка значка). - Десанка Максимовић / Слободан Ж. Марковић: стр. 7-12. - Животопис: стр. 133-152.

111. Антологија српске приче за децу / [приредио] Слободан Ж. Марковић - Београд : Српска књижевна задруга, 1996. - 446 стр. ; 20 cm. - (Антологије / Српска књижевна задруга). - Писци и дела: стр. 429-432. - Поема у стваралаштву за децу / Слободан Ж. Марковић: стр. 435-[447].

112. Весник : песме деце песника Србије. Књ. 2 / [песме изабрали Драган Лукић, Воја Марјановић, Слободан Ж. Марковић]. - Београд : Lingva, 1996. - 167 стр. ; 17 cm. - (Библиотека „Песнички подмладак"). - Стр. 5-7: Весник - будући песници / Воја Марјановић. Стр. 163: Поговор / В. М. [Воја Марјановић]. 
113. Златна књига : антологија књижевног стваралаштва за младе / [приредио] Слободан Ж. Марковић. - Београд : Просвета, 1996. - 468 стр. : илустр. ; 24 cm. - Време „Златне књиге” / С.[Слободан] Ж. М.[Марковић]: стр. 461-463.

114. Изабране приче / Милован Глишић ; избор и пропратни текстови Слободан Ж. Марковић. - Београд : Завод за уџбенике и наставна средства, 1996. - 201 стр. ; 20 cm. - (Библиотека Избор). - Одлике приповедака Милована Глишића: стр. 5-12. - Хронологија живота Милована Глишића: стр. 196-198. - Речник мање познатих речи: стр. 199-200.

115. Ловац срца свога и Тражим помиловање / Десанка Максимовић ; избор и пропратни текстови Слободан Ж. Марковић. - [1. изд.]. - Београд : Завод за уџбенике и наставна средства, 1996. - 162 стр. ; 20 cm. - (Библиотека Избор). - Песнички свет Десанке Максимовић: стр. 5-15. - Хронологија живота и рада Десанке Максимовић: стр. 155-159.

116. Поезија Стевана Раичковића : зборник радова / Десанкини мајски разговори, 14, 15. и 16. маја 1996, Београд, Ваљево, Бранковина ; приређивач Слободан Ж. Марковић. - Београд : Задужбина Десанка Максимовић, 1996. - 134 стр. ; 21 cm

117. Чудесан свет / Десанка Максимовић ; избор и предговор Слободан Ж. Марковић. - Нови Сад : Прометеј : Градска библиотека : Културно-просветна заједница Војводине ; Сремска Митровица : Библиотека „Глигорије Возаревић” ; Вршац : Градска библиотека ; Рума : Градска библиотека ; Суботица : Градска библиотека ; Беочин : Библиотека „Јован Грчић Миленко” ; Житиште : Народна библиотека ; Кула : Народна библиотека ; Неготин : Народна библиотека ; Смедерево : Народна библиотека ; Инђија : Народна библиотека „Др Ђорђе Натошевић” ; Стара Пазова : Народна библиотека „Доситеј Обрадовић” ; Ћуприја : Народна библиотека „Душан Матић” ; Сомбор : Народна библиотека „Карло Бијелицки” ; Ниш : Народна библиотека „Стеван Сремац” ; Кикинда : Народна библиотека „Јован Поповић”, 1996. - 156 стр. ; 20 cm. - (Библиотека Читалачка значка). - Ауторова слика на корицама. - Стр. 7 "12: Десанка Максимовић / Слободан Ж. Марковић. - Стр. 133 ”152: „Ја сам живот волела као ласта---" : животопис Десанке Максимовић / Радован Поповић.

118. Приређивање издања целокупних дела Десанке Максимовић : зборник радова / Десанкини мајски разговори, Београд, Ваљево, Бранковина, 14, 15. и 16. маја 1996. ; приређивач Слободан Ж. Марковић. - Београд : Задужбина Десанка Максимовић, 1997. - 116 стр. ; $21 \mathrm{~cm}$. 
119. Поезија Миодрага Павловића : зборник радова / Десанкини мајски разговори, Београд, Ваљево, Бранковина 14, 15. и 16. маја 1997 ; приредио Слободан Ж. Марковић. - Београд : Задужбина Десанка Максимовић, 1998. - 136 стр. ; 21 cm. - („Десанкини мајски разговори" ; књ. 5).

120. Рецепција дела Десанке Максимовић : зборник радова / Десанкини мајски разговори, Београд, Ваљево, Бранковина, 14, 15. и 16. маја 1997. ; приредио Слободан Ж. Марковић. - Београд : Задужбина Десанка Максимовић, 1998. - 137 стр. : факс. ; 21 cm. - („Десанкини мајски разговори" ; књ. 6).

121. Лађе у пољу : изабране песме / Добрица Ерић ; избор и поговор Слободан Ж. Марковић. - Горњи Милановац : Дечје новине ; Београд : „Драганић”, 1999. - 280 стр. : илустр. ; 24 cm. - (Библиотека Златни лептир ; св. 7). - Ауторова слика. - Поетска казивања деци Добрице Ерића: стр. 273-280. - ISBN 86-367-0831-1.

122. Студије и критике / Јован Скерлић ; избор и пропратни текстови Слободан Ж. Марковић. - [1. изд.]. - Београд : Завод за уџбенике и наставна средства, 1999. - 187 стр. ; 20cm. - (Библиотека Избор). - Јован Скерлић и нова српска књижевност: стр. 7-13. - Мање познате речи: стр. 185-187. - ISBN 86-17-04905-7.

123. Дело Десанке Максимовић у токовима српске и светске књижевности : зборник радова / Десанкини мајски разговори, Београд, Ваљево, Бранковина 13, 14, 15. и 16. маја 1998. ; приредио Слободан Ж. Марковић. - Београд : Задужбина Десанка Максимовић, 2000. - 159 стр. ; 21 cm. -(„Десанкини мајски разговори” ; књ. 8). - Белешке уз текст.

124. Ђаку прваку / [приредио] Слободан Ж. Марковић ; [цртежи ликова писаца Градимир Смуђа]. - 3. поправљено и допуњено изд. - Београд : Народна књига-Алфа, 2000. - 161 стр. : илустр. ; 18 cm. - (Библиотека Петар Пан ; књ. бр. 40). -Податак о илустратору преузет из претходног изд. књиге. - Портрети аутора. - Стр. 7-9: Сусрет са школом и књигом / Слободан Ж. Марковић.

125. Поезија Танасија Младеновића : зборник радова / Десанкини мајски разговори, Београд, Ваљево, Бранковина 13, 14, 15. и 16. маја 1998. ; приредио Слободан Ж. Марковић. - Београд : Задужбина Десанка Максимовић, 2000. - 117 стр. ; 21 cm. - „Десанкини мајски разговори" ; књ. 7). - Белешка о писцу: стр. 115-116.

126. Поезија Борислава Радовића : зборник радова / Десанкини мајски разговори, Београд, Ваљево, Бранковина, 14, 15. и 16. маја 2002. ; приредио Слободан Ж. Марковић. - Београд : Задужбина Десанке Максимовић, 2002. - 63 стр. ; 21 cm. - (Десанкини мајски разговори" ; књ. 15). - ISBN 86-82377-09-8. 
127. Поезија Матије Бећковића : зборник радова / Десанкини мајски разговори, Београд, Ваљево, Бранковина, 14, 15. и 16. маја 1999. ; приредио Слободан Ж. Марковић. - Београд : Задужбина Десанка Максимовић, 2002. - 84 стр. ; 21 cm. - (Десанкини мајски разговори ; књ. 9). - ISBN 86-82377-08-X.

128. Родољубље у поезији Десанке Максимовић : зборник радова / Десанкини мајски разговори, Београд, Лајковац, Бранковина, 13, 15. и 16. маја 2000. ; приредио Слободан Ж. Марковић. - Београд : Задужбина Десанке Максимовић, 2002. - 89 стр. ; 21 cm. - („Десанкини мајски разговори" ; књ. 12). - Белешке уз текст. - ISBN 8682377-06-3.

129. Поезија Милована Данојлића : зборник радова / Десанкини мајски разговори, Београд, Ваљево, Бранковина, 14, 15. и 16. маја ; приредио Слободан Ж. Мирковић. - Београд : Задужбина Десанке Максимовић, 2003. - 107 стр. ; $21 \mathrm{~cm}$. - („Десанкини мајски разговори” ; књ. 11). - Напомене и библиографске референце уз текст. - ISBN 86-82377-10-1.

130. Стваралаштво за децу Десанке Максимовић : зборник радова / Десанкини мајски разговори, Београд, Ваљево, Бранковина, 14, 15. и 16. маја 2002. ; приредио Слободан Ж. Марковић. - Београд : Задужбина Десанке Максимовић, 2003. - 73 стр. ; 21 cm. - („Десанкини мајски разговори" ; књ. 16). - Напомене и библиографске референце уз текст. - ISBN 86-82377-12-8.

131. Десанка Максимовић у деценији 1993-2003 : зборник радова / Десанкини мајски разговори, Београд, Ваљево, Бранковина, 14, 15. и 16. маја 2003. ; приредио Слободан Ж. Марковић. - Београд : Задужбина Десанке Максимовић, 2004 (Београд : Беосинг). - 126 стр. ; $20 \mathrm{~cm}$. - („Десанкини мајски разговори” ; књ. 18). - Напомене и библиографске референце уз поједине радове. - ISBN 86-8237717-9.

132. Задужбина „Десанка Максимовић” : 1993-2003. / [уређивачки одбор Слободан Ж. Марковић, Милош Јевтић, Радован Поповић]. - Београд : Задужбина Десанке Максимовић : Народна библиотека Србије, 2004 (Београд : Беосинг). - 169 стр. : слика Д. Максимовић ; 24 cm. - Библиографија Задужбине Десанка Максимовић: стр. 130-167. - Регистар имена. -ISBN 86-82377-20-9.

133. Поезија Бранислава Петровића : зборник радова / Десанкини мајски разговори, Београд, Ваљево, Бранковина, 14, 15. и 16. маја 2001. ; приредио Слободан Ж. Марковић. - Београд : Задужбина Десанке Максимовић, 2004. - 78 стр. ; 21 cm. - („Десанкини мајски разговори" ; књ. 13). -Бранислав Петровић : (1937-2002): стр. [79]. - Напомене и библиографске референце уз текст. - ISBN 86-82377-18-7. 
134. Поезија Слободана Ракитића : зборник радова / Десанкини мајски разговори, Београд, Ваљево, Бранковина, 14, 15. и 16. маја 2003. ; приредио Слободан Ж. Марковић. - Београд : Задужбина Десанке Максимовић, 2004. - 84 стр. ; 21 cm. - („Десанкини мајски разговори" ; књ. 17). -Напомене и библиографске референце уз текст. - ISBN 86-82377-19-5.

135. Поштована децо : избор поезије / Душан Радовић ; приредио Мирко Марковић ; [илустрације Срђан Ранков]. - Београд : Српска школа, 2008. - 90 стр. : илустр. ; $21 \mathrm{~cm}$. - (Лектира за трећи разред основне школе / [Српска школа]) (Методички обрађена лектира. Трећи разред). - Ауторова слика. - Стр. 5-7: Поетско надигравање Душана Радовића / Мирко Марковић. - Белешка о писцу: стр. 85. - Стр. 87-88: Хајде да причамо / Мирко Марковић. - Стр. 89-90: Други о Душану Радовићу / Бранко В. Радичевић ... [и др.]. - ISBN 978-866025-005-8; ISBN 978-86-6025-002-7 (за издавачку целину).

136. Песме за децу / Десанка Максимовић ; приредили Слободан Ж. Марковић, Зорица Ивковић Савић. - Београд : Задужбина Десанка Максимовић : Службени гласник : Завод за уџбенике, 2012. - 902 стр. ; 25 cm. - (Целокупна дела / Десанка Максимовић ; том 6). - Напомене: стр. 741-880. - Индекс мање познатих речи: стр. 887888. - Регистри. - ISBN 978-86-519-1087-9.

137. Проза за децу / Десанка Максимовић ; приредили Слободан Ж. Марковић, Зорица Ивковић Савић. - Београд : Задужбина Десанка Максимовић : Службени гласник : Завод за уџбенике, 2012. - 994 стр. ; 25 cm. - (Целокупна дела / Десанка Максимовић ; т. 7). - Напомене: стр. 957-985. - ISBN 978-86-519-1088-6.

138. Српске приче за децу : (антологија) / [[приредили] Слободан Ж. Марковић, Мирко С. Марковић]. - Београд : HESPERIAedu, 2015. - 419 стр. : илустр. ; 21 cm. - (Едиција Врт). - Антологијски избор. - Стр. 416-419: Српске приче за децу / Слободан Ж. Марковић, Мирко С. Марковић. - ISBN 978-86-7956-084-1

\section{Чланци}

139. Неке одлике прозног стваралаштва Владана Деснице / Слободан Ж. Марковић // Књижевност и језик. - ISSN 0454-0689. - Год. 5, бр. 6 - 7 (1956), стр. 372-375.

140. Прота Матија Ненадовић / Слободан Ж. Марковић // Књижевност и језик. - ISSN 0454-0689. - Год. 5, бр. 8-9 (1956), стр. 407-425.

141. Проза Ћамила Сијарића / Слободан Ж. Марковић // Књижевност и језик. - ISSN 0454-0689. - Год. 6 , бр. 1-2 (1957), стр. 72-77. 
142. Књижевно дело Јована Поповића / Слободан Ж. Марковић // Књижевност и језик. - ISSN 0454-0689. - Год. 6, бр. 3-4 (1957), стр. 122-130.

143. Проза за децу Иване Брлић - Мажураннић / Слободан Ж. Марковић // Књижевност и језик. - ISSN 0454-0689. - Год. 6, бр. 7-8 (1957), стр. 278-283.

144. Судски процеси Проте Матеје Ненадовића / Слободан Ж. Марковић // Прилози за књижевност, језик, историју и фолклор . - ISSN 0350-6673. - Год 23, св. 1-2 (1957), стр. 93-101.

145. Oskar Davičo, Beton şi licurici / Slobodan Ž. Marković // Lumina. ISSN 0350-4174. - бр. 1-2 (1957), стр. 41-48.

146. Poezia Jugoslava cu motive din lupta eliberare nationala / Slobodan Ž. Marković // Lumina. - ISSN 0350-4174. - бр. 3-4 (1957), стр. 141-152.

147. В. Добросављевић, Књига другова / Слободан Ж. Марковић // Прилози за књижевност, језик, историју и фолклор . - ISSN 0350-6673. - Год. 24, св. 1-2 (1958), стр. 175-177.

148. Књижевност за децу настала између два светска рата на српскохрватском језичком подручју / Слободан Ж. Марковић // Књижевност за децу и рад у дечјим библиотекама. - Београд : Савет друштава за старање о деци и омладини Југославије : Комисија за литературу и штампу за децу, 1958. - стр. 60-70.

149. Књижевност за децу у току и после другог светскогсветског рата / Слободан Ж. Марковић // Књижевност за децу и рад у дечјим библиотекама. - Београд : Савет друштава за старање о деци и омладини Југославије : Комисија за литературу и штампу за децу, 1958. - стр. 70-113.

150. Македонска књижевност за децу (1945 - 1955) / Слободан Ж. Марковић // Књижевност за децу и рад у дечјим библиотекама. Београд : Савет друштава за старање о деци и омладини Југославије : Комисија за литературу и штампу за децу, 1958. - стр. 138-161.

151. Ю. Д. Бельаева, Борба Светозара Марковича за реализам в сербской литературе / Слободан Ж. Марковић // Прилози за књижевност, језик, историју и фолклор . - ISSN 0350-6673. - Год. 25, св. 3 - 4 (1959), стр. 303-305.

152. Књижевност за децу и неки услови за правилно литерарно васпитање / Слободан Ж. Марковић. - Педагошка стварност. - ISSN 0553-4569. - Год. 5, бр. 9 (1959), стр. 682-692.

153. Часопис „Млада култура” / Слободан Ж. Марковић // Студент. ISSN 0039-2693. - бр. 9, 10, 11 и 12 (1959), Подлистак.

154. Нови мотиви у стваралаштву за децу Драгана Лукића / Слободан Ж. Марковић. - Друштво и васпитање. - ISSN 0416-3753. - Год. 10, бр. 2 (1960), стр. 20-24. 
155. Белешка о писцу / Слободан Ж. Марковић // Истините легенде / Јован Поповић. - Београд : Младо поколење, 1961. - (Школска библиотека). - 129-[135].

156. Белешка о писцу / Слободан Ж. Марковић // Приче партизанке / Бранко Ћопић. - Београд : Младо поколење, 1961. - (Школска библиотека). - 89-[96].

157. Жеље и стварност у Ћопићевим делима за децу / Слободан Ж. Марковић // Стремљења. - ISSN 0585-4229. - бр. 2 (1961), стр. 204-217.

158. Изабрана дела / Милован Глишић ; [за штампу приредио Слободан Марковић]. - 2. изд. - Београд : Народна књига, 1961. - 387 стр. ; 20 cm. - (Школска књига). - Књижевни лик Милована Ђ. Глишића / Слободан Ж. Марковић: стр. 5-34. - Савременици о писцу: стр. 351372. - Туђе и мање познате речи: стр. 379-[388]. - Литература.

159. Истините легенде / Јован Поповић. - Београд : Младо поколење, 1961. - 134 стр. ; 20 cm. - (Школска библиотека). - Стране и мање познате речи: стр. 126-128. - Белешка о писцу / Слободан Ж. Марковић: стр. 129-[135].

160. Јован Поповић, партизан и ратни публициста / Слободан Ж. Марковић. - Слика Ј. Поповића // Библиотекар. - ISSN 0006-1816. Год. 13, бр. 5 (1961), стр. 436-444.

161. Неке одлике поезије настале у току народноослободилачке борбе / Слободан Ж. Марковић // Књижевност и језик. - ISSN 0454-0689. - Год. 8, бр. 2 (1961), стр. 167-175.

162. Писма Јована Поповића из народноослободилачке борбе / Слободан Ж. Марковић // Летопис Матице српске. - ISSN 0025-5939. - 137, 387, 6 (јун 1961), стр. 559-575.

163. Почетак публицистичке и књижевне активности у народноослободилачкој борби у Србији 1941. године / Слободан Ж. Марковић // Прилози за књижевност, језик, историју и фолклор . - ISSN 03506673. - Год. 27, св. 3 - 4 (1961), стр. 209-224.

164. Приче партизанке / Бранко Ћопић. - Београд : Младо поколење, 1961. - 95 стр. ; 20 cm. - (Школска библиотека). - Белешка о писцу / Слободан Ж. Марковић: стр. 89-[96].

165. Dobrica Ćosić, Koreni / Slobodan Ž. Marković // Revija. - ISSN 00346888. - br. 5-6 (1961), str. 5-6.

166. Бранислав Нушић, публика и критика / Слободан Ж. Марковић // Стремљења. - ISSN 0585-4229. - Бр. 2, (1962), стр. 194-204.

167. Јован Поповић као књижевни критичар / Слободан Ж. Марковић. Напомене и библиографске референце уз текст // Анали Филолошког факултета. - ISSN 0522-8468. - Књ. 2 (1962), стр. [345]-378. 
168. Треће коло „Књижевности”. (Књижевни портрети у издању „Рада”) / Слободан Ж. Марковић // Књижевност и језик. - ISSN 0454-0689. - Год. 9, бр. 2 (1962), стр. 160-163.

169. Човек и време у књижевном делу Јакова Игњатовића / Слободан Ж. Марковић // Књижевност и језик. - ISSN 0454-0689. - Год. 9, бр. 1 (1962), стр. 27-35.

170. Четири истините легенде Јована Поповића / Слободан Ж. Марковић // Књижевност и језик. - ISSN 0454-0689. - Год. , бр. 2 (1963), стр. 106-115.

171. Međuratni „modernizam” ili ekspresionizam u srpskoj književnosti / Slobodan Ž. Marković // Opera slavica; 4. - Göttingen : Vanderhoeck \& Ruprecht, [1963]. - Str. 143-149.

172. Бојан Ничев, „Бранислав Нушић” / Слободан Ж. Марковић // Бранислав Нушић, 1864-1964. - Београд : Позоришни музеј, 1965. - стр. 387-390.

173. Друштвени и литерарни аспекти покрета социјалне књижевности / Слободан Ж. Марковић // Књижевност и језик. - ISSN 0454-0689. - Год. 11, бр. 2 (1964), стр. 19-33.

174. Друштвено ангажована поезија Јована Поповића / Слободан Ж. Марковић // Стремљења. - ISSN 0585-4229. - Бр. 2 (1964), стр. 173-184.

175. Опасност есејистичког уопштавања (Поводом „Пет песника” Д. Грбића) / Слободан Ж. Марковић // Књижевност и језик. - ISSN 04540689. - Год. 11, бр. 1 (1964), стр. 69-72.

176. Разнородност и јединство Скерлићеве личности / Слободан Ж. Марковић // Књижевност и језик. - ISSN 0454-0689. - Год. 11, бр. 3 (1964), стр. 43-53.

177. Expresszionizmus a jugoszláv irodalomban / Slobodan Ž. Marković ; (fordította Csuka Zoltán) // Helikon. - ISSN 0017-999X. - br. 2/3 (1964). - str. 195-206.

178. Laza Lazarević / Slobodan Ž. Marković. - 2. redigovano izd. - Beograd : Rad, 1964. - 38 str. ; 17 cm. - (Književnost / Radnički univerzitet ; kolo 4).

179. Београдски надреализам / Слободан Ж. Марковић // Књижевност и језик. - ISSN 0454-0689. - Год. 12, бр. 4 (1965), стр. [1]-23.

180. Елементи народног стваралаштва у делу М. Лалића и В. Попе / Слободан Ж. Марковић // Багдала. - ISSN 0005-3880. - бр. 70-71 (1965), стр. 2.

181. Народноослободилачка борба у књижевности / Слободан Ж. Марковић // Књижевност и језик. - ISSN 0454-0689. - Год. 12, бр. 1 (1965), стр. 21-24. 
182. Неки проблеми изучавања најновије југословенске књижевности / Слободан Ж. Марковић // Књижевност и језик. - ISSN 0454-0689. - Год. 12, бр. 3 (1965), стр. 43-51.

183. Поговор / Слободан Ж. Марковић // Избор приповедака / Милован Глишић. - Београд : Народна књига, 1965. - (Југословенски класици). - стр. 207-214.

184. Позоришна критика Јована Поповића / Слободан Ж. Марковић // Позориште. - ISSN 0032-616X. - бр. 4 -5 (1965), стр. 468-475.

185. Пут од историје до књижевности / Слободан Ж. Марковић // Борба. - ISSN 1451-6608. - (9. септембар 1965), стр. 11.

186. Фолклор у савременој књижевности / Слободан Ж. Марковић // Анали Филолошког факултета. - ISSN 0522-8468. - Књ. 4 (1965), стр. 249-263.

187. Часопис „Нова литература” и Издавачко предузеће „Нолит” / Слободан Ж. Марковић // Књижевност и језик. - ISSN 0454-0689. - Год. 12, бр. 2 (1965), стр. [7]-14.

188. „Dečja književnost” i „književnost za decu” / Slobodan Ž. Marković // Umjetnost riječi. - ISSN 0503-1583. - br. 1 (1965), str. 95-102.

189. NOB u književnosti za decu / Slobodan Ž. Marković // Dialogi. - ISSN 0012-2068. - br. 7-8 (1965), str. 423-427.

190. Витомир Вулетић, „Светозар Марковић и руски револуционарни демократи" / Слободан Ж. Марковић // Прилози за књижевност, језик, историју и фолклор . - ISSN 0350-6673. - Год. 32, св. 1-2 (1966), стр. 107-109.

191. Јован Поповић / Слободан Ж. Марковић // Изабрана дела / Јован Поповић. - Београд : Народна књига, 1966. - стр. 5-18.

192. Неколико одлика књижевности за децу са тематиком из НОБ-е / Слободан Ж. Марковић. - Стремљења. - ISSN 0585-4229. - Бр. 3 (1966), стр. 185-195.

193. О настави матерњег језика и књижевности / Слободан Ж. Марковић // Политика. - ISSN 0350-4395. - (27. јануар 1966).

194. О Николетини Бурсаћу и његовом писцу / Слободан Марковић // Доживљаји Николетине Бурсаћа / Бранко Ћопић ; [поговор Слободан Марковић ]. - Београд : Младо поколење, 1966. - (Лектира за VIII разред основне школе). - стр. 179-182.

195. Педагог и научник др Драгољуб Павловић. (Некролог) / Слободан Ж. Марковић // Борба. - ISSN 1451-6608. - (14. август 1966), (ненумерисано).

196. Родољубива поезија J. Ј. Змаја, А. Шантића, М. Ракића и В. Петровића / Слободан Ж. Марковић // Песме / Јован Јовановић Змај... [и др.]. - Београд : [б. и.], 1966. - стр. 85-95. 
197. Ћопићева Пионирска трилогија / Слободан Ж. Марковић // Пионирска трилогија / Бранко Ћопић. - Београд : Просвета ; Сарајево : Веселин Маслеша, 1966. - стр. 311-314.

198. Исидора Секулић. Есеји о јусгословенској књижевности / Слободан Ж. Марковић // Књижевност и језик. - ISSN 0454-0689. - Год. 14, бр. 1-2 (1967), стр. 15-30.

199. Неке одлике приповедне прозе Коче Рацина / Слободан Ж. Марковић // Четврти Рацинови средби. - Титов Велес : Советот на Рациновите средби, 1967. - стр. 38-45.

200. Проза Исидоре Секулић / Слободан Ж. Марковић. - Стремљења. - ISSN 0585-4229. - Бр. 2 (1967), стр. 134-150.

201. Ратна тема и јунаци у романима за децу који говоре о НОБ / Слободан Ж. Марковић // Кораци. - ISSN 0454-3566. - Бр. 2 (1967), стр. 5-11.

202. Вељко Петровић... / Слободан Марковић // Родољубиве песме / Јован Јовановић Змај ... [и др.]. - Београд : Младо поколење, 1968. - (Лектира за VIII разред основне школе ; књ. 5). - Стр. 92-93.

203. Десанка Максимовић / Слободан Ж. Марковић // Књижевност и језик. - ISSN 0454-0689. - Год. 15, бр. 4 (1968), стр. 1-8.

204. Драме Кола Чашула / Слободан Ж. Марковић // Пети Рацинови средби. - Титов Велес : Советот на Рациновите средби, 1968. - стр. 132-141.

205. Друштвена основа пута београдских надреалиста ка социјалној литератури / Слободан Ж. Марковић // Прилози за књижевност, језик, историју и фолклор: ISSN 0350-6673. - Год. 34, св. 3-4 (1968). - Стр. 237-244.

206. Личност и књижевна реч Михала Петровића / Слободан Ж. Марковић / / Споменица о свечаном скупу поводом прославе 100-годишњице од рођења Михаила Петровића 1868-1968 / ур. Вукић М. Мићовић. - Београд: САНУ, 1968. - стр. 345-353.

207. О Николетини Бурсаћу и његовом писцу / Слободан Марковић // Доживљаји Николетине Бурсаћа / Бранко Ћопић ; [поговор Слободан Марковић]. - Београд : Младо поколење, 1968. - (Лектира за VIII разред основне школе ; књ. 1). - стр. 167-170.

208. Романсијер Славко Јаневски / Слободан Ж. Марковић // Две Марије : роман / Славко Јаневски ; предговор Слободан А. [тј. Ж.] Марковић. - Београд : Просвета, 1968. - (Библиотека Просвета ; 215). - стр. 5-12.

209. Pogovor o piscu i njegovu delu / Slobodan Ž. Marković // Orlovi rano lete ; Slavno vojevanje / Branko Ćopić. - Beograd : Mlado pokolenje, 1968. - (Lektira za VI razred osnovne škole / Mlado pokolenje ; knj. 2). - str. 315-[318]. 
210. Аутономност, субјективност, игра и осећајност / Слободан Ж. Марковић // Књижевност и језик. - ISSN 0454-0689. - Год. 16, бр. 4 (1969), стр. 414-422.

211. Аутономност, субјективност, игра и осећајност / Слободан Ж. Марковић // Umjetnost i dijete. - ISSN 0503-1575. - Br. 4-5 (1969), стр. $19-23$.

212. О јединству савремене књижевности / Слободан Ж. Марковић // Трагом дечје песме. - Нови Сад : Змајеве дечје игре ; Културни центар, 1969. - стр. 51-58.

213. Токови наше савремене књижевности за децу / Слободан Ж. Марковић. - Стремљења. - ISSN 0585-4229. - Бр. 2 (1969), str. 149-161.

214. Jovan Jovanović Zmaj i poezija za decu - jedan vid poetike / Slobodan Ž. Marković // Umjetnost i dijete. - ISSN 0503-1575. - Br. 1 (1969), str. 28-32.

215. Вељко Петровић... / Слободан Ж. Марковић // Родољубиве песме / Јован Јовановић Змај ... [и др.]. - Београд : Младо поколење, 1970. - (Лектира за VIII разред основне школе ; књ. 5). - Стр. 92-93.

216. Љубав је мерило људске среће у „Сеобама” / Слободан Ж. Марковић. - Стремљења. - ISSN 0585-4229. - Бр. 4 (1970), стр. 419-429.

217. Млади Растко Петровић / Слободан Ж. Марковић // Књижевност и језик. - ISSN 0454-0689. - Год. 17, бр. 3-4 (1970), стр. 341-349.

218. О Николетини Бурсаћу и његовом писцу / Слободан Ж. Марковић // Доживљаји Николетине Бурсаћа / Бранко Ћопић ; [поговор Слободан Марковић ; илустровао Зуко Џумхур]. - Београд : Младо поколење, 1970. - (Лектира за VIII разред основне школе / Младо поколење, Београд ; књ. 1). - стр. 167-170.

219. Одзвуци на народните умотворби во поезијата на Блажо Конески / Слободан Ж. Марковић // Шести Рацинови средби. - Титов Велес : Советот на Рацинови средби, 1970. - стр. 192-203.

220. Deo jedne životne celine / Slobodan Ž. Marković // Dečja književnost - šta je to?. - Novi Sad : Zmajeve dečje igre ; Kulturni centar, 1970. - str. 44-52.

221. Deo jedne životne celine / Slobodan Ž. Marković // Jezik in slovstvo. - ISSN 0021-6933. - Br. 1-2 (1970), str. 14-18.

222. Odjeci narodnih umotvorina u poeziji Bleže Koneskog / Slobodan Ž. Marković // Književna kritika. - ISSN 0350-4123. - Br. 1 (1970), str. 88-94.

223. Pogovor o piscu i njegovom delu / Slobodan Ž. Marković // Orlovi rano lete / Branko Ćopić ; [pogovor Slobodan Ž. Marković]. - Beograd : Mlado pokolenje, 1970 . - (Lektira za VI razred osnovne škole ; knj. 2). - str. 317-320. 
224. Realni čovek je centralni lik u fantastičnom svetu Ivane Brlić Mažuranić / Slobodan Ž. Marković // Ivana Brlić Mažuranić. - Zagreb : Mladost, 1970. - str. 118-129.

225. Национална књижевност у породици светске литературе / Слободан Ж. Марковић // Седми рацинови средби. - Титов Велес : Советот на Рацинови средби, 1971. - стр. 58-68.

226. Нем за прву љубав / Слободан Ж. Марковић // Борба. - ISSN 03507440. - Год. 49, бр. 83 (27. III 1971), стр. 8.

227. Поговор / Слободан Ж. Марковић // Доживљаји Николетине Бурсаћа / Бранко Ћопић ; [поговор Слободан Ж. Марковић ; дидактичко-методичка апаратура Оливера Бакочевић ; текст илустровао Зуко Џумхур]. - Београд : Младо поколење, 1971. - (Лектира за VIII разред основне школе ; књ. 6). - стр. 170-173.

228. Pogovor / Slobodan Ž. Marković // Orlovi rano lete ; Slavno vojevanje / Branko Ćopić ; [pogovor Slobodan Ž. Marković ; didaktičko-metodička aparatura Biserka Jovanović]. - Beograd : Mlado pokolenje, 1971. - (Lektira za VI razred osnovne škole ; knj. 6). - str. 329-332.

229. Време „Младе културе” или време неизвесности / Слободан Ж. Марковић // Млада култура. - ISSN 0462-9558. - бp. 1 (1972), стр. $58-65$.

230. Зенитизам / Слободан Ж. Марковић // Књижевност и језик. - ISSN 0454-0689. - Год. 19, бр. 2-3 (1972), стр. 81-86.

231. Наше доба и детињство у књизи Палме Каталинић / Слободан Ж. Марковић // Критика књижевности за децу. - Нови Сад : Змајеве дечје игре, 1972. - стр. 118-125.

232. Први корак у узајамном упознавању / Слободан Ж. Марковић // Књижевне новине. - ISSN 0023-2416. - Бр. 426 (1. новембар 1972), стр. 1.

233. Радозналост и активност, видна обележја поетског света детињства у стиховима Григора Витеза / Слободан Ж. Марковић // Багдала. - ISSN 0005-3880. - Бр. 5 (1972), стр. 5-7.

234. Српска култура у односу на стране културе / Слободан Ж. Марковић // Конгрес културне акције у СР Србији / [уредник] Милорад Гончин. - [Београд] : Републичка конференција ССРН СР Србије, 1972. - Стр. 783-787.

235. Mladinska knjiga v družini / Slobodan Ž. Marković // Otrok in knjiga. - ISSN 0351-5141. - Br. 1 (1972), str. 43-48.

236. Елементи неоромантизма у срспској књижевности између два светска рата / Слободан Ж. Марковић // Прилози за књижевност, језик, историју и фолклор. - ISSN 0350-6673. - Бр. 1-2 (1973), стр. 41-48. 
237. Идеја друштвене ангажованости у књижевности између два светска рата / Слободан Ж. Марковић // Књижевност и језик. - ISSN 0454-0689. - Год. 20, бр. 3-4 (1973).

238. Комуникативност савремене књижевности / Слободан Ж. Марковић // Девети Рацинови средби. - Титов Велес : Советот на Рацинови средби, 1973. - стр. 47-55.

239. Ликови и структура Истинитих легенди Јована Поповића / Слободан Ж. Марковић // Савремена проза / приредио М. И. Бандић. Београд : Нолит, 1973. - (Српска књижевност у књижевној критици ; 10). - Стр. 289-[299].

240. Pogovor / Slobodan Ž. Marković // Orlovi rano lete ; Slavno vojevanje / Branko Ćopić ; [pogovor Slobodan Ž. Marković]. - Beograd : Nolit, 1973. - (Lektira za VI razred osnovne škole ; knj. 6). - str. 329-332.

241. Поетске слике у поезији Коче Рацина / Слободан Ж. Марковић // Десети Рацинови средби. - Титов Велес : Советот на Рацинови средби, 1974. - стр. 105-114.

242. „Хасанагиница” и драмско дело Љубомира Симовића / Слободан Ж. Марковић // Научни састанак слависта у Вукове дане. - ISSN 0351-9066 МСЦ. - Књ. 4, св. 1 (1974), стр. 579-587.

243. Замишљен над судбином, задивљен пред снагом човека. (Човекова драма у поезији Блаже Конеског) / Слободан Ж. Марковић // Борба. - ISSN 1451-6608. - (8. новембар 1975), стр. 13.

244. Мисао Белинског и српска социјална књижевност између два светска рата / Слободан Ж. Марковић // Наслеђе естетичке и књижевно - критичке мисли Белинског. - Београд : Међународни славистички центар, 1975. - стр 133-137.

245. Проза за децу о НОБ-у и револуцији / Слободан Ж. Марковић // Књижевност у НОБ-у и револуцији. - Београд : (б.и.), 1975. - стр. 151-155.

246. Социјална књижевност и Светозар Марковић / Слободан Ж. Марковић // Светозар Марковић и српска књижевност. - Београд : Институт за књиевност и уметност ; Нолит, 1975. - стр. 229-234.

247. У великом, заједничком Идењу. (Седамдесет година од рођења Јована Поповића) / Слободан Ж. Марковић // Борба. - ISSN 14516608. - (15. новембар 1975), стр. 11.

248. Nekoliko zapisa na marginama kalendara Ćopićevog stvaralaštva za decu / Slobodan Ž. Marković // Detinjstvo. - ISSN 0350-5286. - God. 1, br. 1 (1975), str. 27-32.

249. Иво Андрић / Слободан Ж. Марковић. - Додатак: Венчева школска лектира / избор Слободан Ж. Марковић // Венац. - ISSN 0350-3364. - Год. 4, бр. 43 (март 1976), стр. 69. 
250. Светот на фантазијата и реалноста на Бранко Копик / Слободан Ж. Марковик // Градината со слезова боја / Бранко Ћопик ; [превод од српскохрватски Тодор Димитровски]. - Скопје : Култура : Мисла : Наша книга : Македонска книга : Нова Македонија, 1976. - (Странски и југословенски автори). -Превод дела: Башта сљезове боје / Бранко Ћопић. - Стр. 212-222.

251. Ставови међуратних писаца и стваралачки однос Растка Петровића према фоклору / Слободан Ж. Марковић // Научни састанак слависта у Вукове дане. - ISSN 0351-9066. - Год. 6, св. 2 (1976), стр. 273-281.

252. Pogovor / Slobodan Ž. Marković // Orlovi rano lete ; Slavno vojevanje / Branko Ćopić ; [pogovor Slobodan Ž. Marković ; didaktičko-metodička aparatura Biserka Jovanović]. - Beograd : Nolit, 1976. - (Lektira za VI razred osnovne škole ; knj. 11). - str. 377-380.

253. Prilog razmatranju teme "Mladi i književnost o ratu i revoluciji” / Slobodan Ž. Marković. - (Revolucija i književnost za decu) // Ulaznica. - ISSN 0503-1362. - God. 11, br. 60 (1977), str. 55-60.

254. Поговор / Слободан Ж. Марковић //Доживљаји Николетине Бурсаћа / Бранко Ћопић ; илустрације Зуко Џумхур ; [дидактичко-методички текст Оливера Бакочевић ; поговор Слободан Ж. Марковић]. - Београд : Нолит : Просвета : Завод за уџбенике и наставна средства, 1978 (Београд : Београдски издавачко-графичи завод). - (Лектира за VIII разред основне школе ; 4). - стр. 185-189.

255. Сучељавање смрти и живота у роману Славка Јаневског / Слободан Ж. Марковић // И бол и бес / Славко Јаневски. - Нови Сад : Матица српска, 1978. - (Македонска књижевност). - Стр. 5-19.

256. Die Verbindungen zwischen der progressiven deutschen Literatur und einer Richtung der sozialen Literatur in Jugoslawien der 20er und 30er Jahre / S. Ž. Marković // Zeitschrift für Slawistik, Bd. XXIII, Heft 3. - Berlin : Akademie-Verlag, 1978. - Str. 352-363.

257. Expressionismus bei den Belgrader Schriftstellern : 1924-1928 / Slobodan Ž. Marković // Innsbrucker Beiträge zur Kulturwissenschaft. Sonderheft, 43. - Innsbruck : AMOE, 1978. - Str. 67-71.

258. Поговор / Слободан Ж. Марковић // Орлови рано лете / Бранко Ћопић ; илустрације Ђорђе Милановић ; [дидактичко-методички текст Бисерка Јовановић ; поговор Слободан Ж. Марковић]. - [2. изд.]. - Београд : Нолит : Просвета : Завод за уџбенике и наставна средства, 1979. - (Лектира за VI разред основне школе ; 4). - стр. 201-205.

259. Поговор / Слободан Ж. Марковић // Поеме / Александар Вучо, Стеван Раичковић, Добрица Ерић ; илустрације Владимир Тјапкин ; 
[поговор Слободан Марковић ; дидактичко-методички текстови Бисерка Јовановић, Оливера Бакочевић]. - [2. изд.]. - Београд : Нолит : Просвета : Завод за уџбенике и наставна средства, 1979. - (Лектира за IV разред основне школе ; 6). - стр. 265-270.

260. Поговор / Слободан Ж. Марковић // Поеме / Александар Вучо, Стеван Раичковић, Добрица Ерић ; илустрације Владимир Тјапкин ; [поговор Слободан Марковић ; дидактичко-методички текстови Бисерка Јовановић, Оливера Бакочевић]. - [3. изд.]. - Београд : Нолит : Просвета : Завод за уџбенике и наставна средства, 1979. - (Лектира за IV разред основне школе ; 6). - стр. 265-270.

261. Поговор / Слободан Ж. Марковић // Доживљаји Николетине Бурсаћа / Бранко Ћопић ; илустрације Зуко Џумхур ; [дидактичко-методички текст Оливера Бакочевић ; поговор Слободан Ж. Марковић]. - 2. изд. - Београд : Нолит : Просвета : Завод за уџбенике и наставна средства, 1980. - (Лектира за VIII разред основне школе ; 4). - стр. 185-189.

262. Поговор / Слободан Ж. Марковић // Орлови рано лете / Бранко Ћопић ; илустрације Ђорђе Милановић ; [дидактичко-методички текст Бисерка Јовановић ; поговор Слободан Ж. Марковић]. - [3. изд.]. - Београд : Нолит : Просвета : Завод за уџбенике и наставна средства, 1980. - (Лектира за VI разред основне школе ; 4). - стр. 201-205.

263. Поговор / Слободан Ж. Марковић // Поеме / Александар Вучо, Стеван Раичковић, Добрица Ерић ; илустрације Владимир Тјапкин ; [дидактичко-методички текстови Бисерка Јовановић и Оливера Бакочевић ; поговор Слободан Ж. Марковић]. - [4. изд.]. - Београд : Нолит : Просвета : Завод за уџбенике и наставна средства, 1980. - (Лектира за IV разред основне школе ; 6). - стр. 265-270.

264. Bajkoviti svet / Slobodan Ž. Marković. - Prikaz knjige: Grozdana Olujić: Sedefna ruža i druge bajke, Zagreb, 1979 // Detinjstvo. - ISSN 0350-5286. - God. 6, br. 4 (1980), str. 52-54.

265. Čime završavamo osmu deceniju ovog veka / Slobodan Ž. Marković // Detinjstvo. - ISSN 0350-5286. - God. 6, br. 4 (1980), str. 20-24.

266. Pojam i ime književnosti za decu / Slobodan Ž. Marković // Detinjstvo. - ISSN 0350-5286. - God. 6, br. 2 (1980), str. 60-68.

267. Културна и књижевна активност на почетку устанка у Србији 1941. / Слободан Ж. Марковић // Књижевност и језик. - ISSN 0454-0689. - Год. 28, бр. 3/4 (1981), стр. [211]-219.

268. Поговор / Слободан Ж. Марковић // Доживљаји Николетине Бурсаћа / Бранко Ћопић ; илустрације Зуко Џумхур ; [дидактичко-методички текст Оливера Бакочевић ; поговор Слободан Ж. Марко- 
вић] . - [3. изд.]. - Београд : Нолит : Просвета : Завод за уџбенике и наставна средства, 1981 . - (Лектира за VIII разред основне школе ; 4). - стр. 185-189.

269. Поговор / Слободан Ж. Марковић // Орлови рано лете / Бранко Ћопић ; илустрације Ђорђе Милановић ; [дидактичко-методички текст Бисерка Јовановић ; поговор Слободан Ж. Марковић]. - [4. изд.]. - Београд : Нолит : Просвета : Завод за уџбенике и наставна средства, 1981 . - (Лектира за VI разред основне школе ; 4). - стр. 201-205.

270. Поговор / Слободан Ж. Марковић // Поеме / Александар Вучо, Стеван Раичковић, Добрица Ерић ; илустрације Владимир Тјапкин ; [дидактичко-методички текстови Бисерка Јовановић и Оливера Бакочевић ; поговор Слободан Ж. Марковић]. - [5. изд.]. - Београд : Нолит : Просвета : Завод за уџбенике и наставна средства, 1981 . - (Лектира за IV разред основне школе ; 6). - стр. 265-270.

271. Поговор / Слободан Ж. Марковић // Поеме / Александар Вучо, Стеван Раичковић, Добрица Ерић ; илустрације Владимир Тјапкин ; [дидактичко-методички текстови Бисерка Јовановић и Оливера Бакочевић ; поговор Слобдан Ж. Марковић]. - [5. изд.]. - Београд : Нолит : Просвета : Завод за уџбенике и наставна средства, 1982. - (Лектира за IV разред основне школе ; 6). - стр. 265-270.

272. Proza za decu u 1981. / Slobodan Ž. Marković // Detinjstvo. - ISSN 0350-5286. - God. 8, br. 1/2 (1982), str. 61-65.

273. Поговор / Слободан Ж. Марковић // Поеме / Александар Вучо, Стеван Раичковић, Добрица Ерић ; илустрације Владимир Тјапкин ; [дидактичко-методички текстови Бисерка Јовановић и Оливера Бакочевић ; поговор Слобдан Ж. Марковић]. - 6. изд. - Београд : Нолит : Просвета : Завод за уџбенике и наставна средства, 1983. - 275 стр. : илустр. ; 18 cm. - (Лектира за IV разред основне школе ; 6). - стр. 265-270.

274. Поговор / Слободан Ж. Марковић // Доживљаји Николетине Бурсаћа / Бранко Ћопић ; илустрације Зуко Џумхур ; [дидактичко-методички текст Оливера Бакочевић ; поговор Слободан Ж. Марковић]. - [4. изд.]. - Београд : Нолит : Просвета : Завод за уџбенике и наставна средства, 1983. - 193 стр. : илустр. ; 18 cm. - (Лектира за VIII разред основне школе ; 4). - стр. 185-189.

275. Поговор / Слободан Ж. Марковић // Орлови рано лете / Бранко Ћопић ; илустрације Ђорђе Милановић ; [дидактичко-методички текст Бисерка Јовановић ; поговор Слободан Ж. Марковић]. - [5. изд.]. - Београд : Нолит : Просвета : Завод за уџбенике и наставна средства, 1983. - 206 стр. : илустр. ; $18 \mathrm{~cm}$. - (Лектира за VI разред основне школе ; 4). - стр. 201-205. 
276. Pesnikov zov na igru , „Taši, taši, tanana!” / Slobodan Ž. Marković. - O Zmajevoj pesmi „Taši, taši” // Detinjstvo. - ISSN 0350-5286. - God. 9, br. 1/2 (1983), str. 79-80.

277. Културна и књижевна активност на почетку устанка у Србији 1941 / Слободан Ж. Марковић // Kultura i nauka u narodnooslobodilačkom ratu i revoluciji / redaktor Mihailo Apostolski. - Skopje : Savet akademija nauka i umetnosti SFRJ, 1984. - стр. 237-246.

278. Поговор / Слободан Ж. Марковић // Поеме / Александар Вучо, Стеван Раичковић, Добрица Ерић ; илустрације Владимир Тјапкин ; [дидактичко-методички текстови Бисерка Јовановић и Оливера Бакочевић ; поговор Слобдан Ж. Марковић] . - 7. изд. - Београд : Нолит : Просвета : Завод за уџбенике и наставна средства, 1984. - 275 стр. ; 18 cm. - (Лектира за IV разред основне школе ; 6). - стр. 265-270.

279. Поговор / Слободан Ж. Марковић // Орлови рано лете / Бранко Ћопић ; илустрације Ђорђе Милановић ; [дидактичко-методички текст Бисерка Јовановић ; поговор Слободан Ж. Марковић] . - [6. изд.]. - Београд : Нолит : Просвета : Завод за уџбенике и наставна средства, 1984. - 206 стр. : илустр. ; $18 \mathrm{~cm}$. - (Лектира за VI разред основне школе ; 4). - стр. 201-206.

280. Предговор / Слободан Ж. Марковић // На другој обали : хрестоматија послератне књижевности на српскохрватском језику у Мађарској / саставио и поговор написао Петар Милошевић. - Ваљево : „Милић Ракић” ; Београд : Културно-просветна заједница Србије, 1984. - 172 стр. ; 21 ст. - стр. 5-8.

281. Стваралачки поступак Вељка Петровића у приповеткама о деци и о детињству / Слободан Ж. Марковић // Дело Вељка Петровића. - Нови Сад : Матица српска, 1985. - Стр. 191-195.

282. Више од сведочанства / Слободан Ж. Марковић // Кућа смрти / Велибор Глигорић. - Београд : Фонд „Велибор Глигорић” Филолошког факултета ; Ваљево : „Милић Ракић”, 1985. - 100 стр. ; 20 cm. - (Библиотека Заједничка издања ; књ. 6). - стр. 97-100.

283. Поговор / Слободан Ж. Марковић // Поеме / Александар Вучо, Стеван Раичковић, Добрица Ерић ; илустрације Владимир Тјапкин ; [дидактичко-методички текстови Бисерка Јовановић и Оливера Бакочевић ; поговор Слобдан Ж. Марковић]. - 8. изд. - Београд : Нолит : Просвета : Завод за уџбенике и наставна средства, 1985. - 275 стр. : илустр. ; $18 \mathrm{~cm}$. - (Лектира за IV разред основне школе ; 6). - стр. 265-270.

284. Поговор / Слободан Ж. Марковић // Доживљаји Николетине Бурсаћа / Бранко Ћопић ; илустрације Зуко Џумхур . - [5. изд.]. - 
Београд : Нолит : Просвета : Завод за уџбенике и наставна средства, 1985. - 193 стр. : илустр. ; 18 cm. - (Лектира за VIII разред основне школе ; 4). - стр. 185-189.

285. Želje i stvarnost u Ćopićevim delima za decu / Slobodan Ž. Marković // Delije na Bihaću / Branko Ćopić. - Sarajevo : Svjetlost : „Veselin Masleša", 1985. - (Sabrana djela Branka Ćopića ; knj. 15). - Str. 301-324.

286. Stevan - Steva Raičković / Slobodan Ž. Marković // Detinjstvo. - ISSN 0350-5286. - God. 11, br. 3/4 (1985), str. 7-9.

287. Вук и његови ученици / Слободан Ж. Марковић // Политика. - ISSN 0350-4395. - (6. нов. 1986), стр. 9.

288. Заљубљеник наставничког позива - Димитрије Вученов (1911-1986) / Слободан Ж. Марковић // Књижевност и језик. - ISSN 0454-0689. - бр. 3-4 (1986), стр. 95-101.

289. Поговор / Слободан Ж. Марковић // Гурије / Стеван Раичковић ; дидактичко-методички текст Оливера Бакочевић ; поговор Слободан Ж. Марковић ; илустровао Владимир Тјапкин. - Београд : Нолит, 1986. - 64 стр. : илустр. ; $18 \mathrm{~cm}$. - (Лектира за $\mathrm{V}$ разред основне школе ; 8). - стр. 61-63.

290. Поговор / Слободан Ж. Марковић // Орлови рано лете / Бранко Ћопић ; дидактичко-методички текст Бисерка Јовановић ; поговор Слободан Ж. Марковић. - Београд : Нолит, 1986. - 194 стр. ; $18 \mathrm{~cm}$. - (Лектира за VI разред основне школе ; 2). - стр. 189-193.

291. Kultura ne trpi granice / Slobodan Ž. Marković // Kulturni život. ISSN 0023-5261. - God. 28, br. 4-5(1986), str. 182-183.

292. Roman Bezdušnici Lazara Komarčića u tokovima srpske realističke proze / Slobodan Ž. Marković // Lazar Komarčić u svom i našem vremenu / [urednik Vuko Bezarević. - Priboj na Limu : SIZ kulture Priboj ; Pljevlja : Međurepublička zajednica za kulturno-prosvjetnu djelatnost, 1986. - (Biblioteka Limskih večeri poezije). - Str. 13-20.

293. Радозналост, љубав, историја / Слободан Ж. Марковић // Ваљево у прошлости : прилози за завичајну историју / Радован М. Драшковић ; [библиографију и регистар урадио Милан Р. Драшковић].. - [1. изд.]. - Ваљево : „Милић Ракић”, 1987. - 387 стр. : табеле ; 25 cm. - (Библиотека Посебна издања / „Милан Ракић”, Ваљево ; књ. 9). - стр. 5-8.

294. Књижевна мисао Вука Караџића и српски реализам : (Светозар Марковић, баштиник дела Вука Караџића) / Слободан Ж. Марковић. - Научни састанак слависта у Вукове дане 1987 // Научни састанак слависта у Вукове дане. - ISSN 0351-9066. - Књ. 17, св. 4 (1988), стр. 145-154.

295. Поговор / Слободан Ж. Марковић // Гурије / Стеван Раичковић ; дидактичко-методички текст Оливера Бакочевић ; поговор Слободан 
Ж. Марковић ; илустровао Владимир Тјапкин. - [3. изд.]. - Београд : Нолит, 1988. - 64 стр. : илустр. ; $18 \mathrm{~cm}$. - (Лектира за V разред основне школе ; 8). - стр. 61-63.

296. Поговор / Слободан Ж. Марковић // Дјечак прати змаја [Брајево писмо] : у две свеске. Св. 2 / Бранко Ћопић. - Београд : „Филип ВИшњић", 1988. - 146 стр. ; 34 cm. - стр. 139-144.

297. Поговор / Слободан Ж. Марковић // Порука непријатељу / Алек Марјано ; [илустрације Миомир Томић]. - Београд : Трајна радна заједница писаца „Раковица”, 1988. - 40 стр. : илустр. ; 19 цм. - (Дечја библиотека Огледалце). - стр. 38-40.

298. Поговор / Слободан Ж. Марковић // Орлови рано лете / Бранко Ћопић ; дидактичко-методички текст Бисерка Јовановић ; поговор Слободан Ж. Марковић. - [3. изд. ]. - Београд : Нолит, 1988. - 194 стр. ; 18 цм. - (Лектира за ВИ разред основне школе / Нолит ; 2). - стр. 189-193.

299. Поговор / Слободан Ж. Марковић // Доживљаји Николетине Бурсаћа / Бранко Ћопић ; поговор Слободан Ж. Марковић ; дидактичко-методички текст Оливера Бакочевић. - Београд : Нолит, 1988. - 169 стр. ; 19 cm. - (Лектира за VIII разред основне школе ; 4). - стр. 162-166.

300. Појава и особености српског симболизма / Слободан Ж. Марковић // Анали Филолошког факултета. - ISSN 0522-8468. - 19 стр. 349-361.

301. Предговор / Слободан Ж. Марковић // Најдражи учитељ / Мирјана Анастасијевић ...[и др.] ; [предговор Слободан Ж. Марковић]. - Горњи Милановац : Дечје новине ; Београд : Културно-просветна заједница Србије, 1988 . - 311 стр. : илустр. ; 20 cm. - стр. 7-10.

302. Приврженост омладине Васи Стајићу / Слободан Ж. Марковић. - Надређени ств. насл.: Лик Васе Стајића: округли сто посвећен накадашњем секретару и председнику Матице српске // Свеске Матице српске. Серија друштвених наука. - ISSN 0352-7719. - 3(8) (1988), стр. 7-10.

303. Mirko Petrović : (1927-1988) / Slobodan Ž. Marković // Detinjstvo. - ISSN 0350-5286. - God. 14, br. 4 (1988), str. 7-8.

304. Rivalstvo ljubavi i nedaća / Slobodan Ž. Marković. - Prikaz knjige: Vladimir Stojšin: Šampion kroz prozor, Beograd, 1987 // Detinjstvo. - ISSN 0350-5286. - God. 14, br. 1/2 (1988), str. 103-104.

305. Uslovnost termina „književnost NOB-a” ili „književnost sa tematikom iz NOB-a" / Slobodan Ž. Marković // Detinjstvo. - ISSN 0350-5286. - God. 14, br. 1/2 (1988), str. 7-10.

306. Значај Вука Караџића за почетак рада Велике школе / Слободан Ж. Марковић. - Саопштења и прилози са Симпозијума одржаног у 
Београду 15-17. новембра 1988. Године // Научни састанак слависта у Вукове дане. - ISSN 0351-9066. - Стр. 19-26.

307. Историчност, завичајност и отаџбинство / Слободан Ж. Марковић // Књижевност и језик. - ISSN 0454-0689. - Год. 36, бр. 3 (1989), стр. 263-268.

308. Поговор / Слободан Ж. Марковић // Гурије / Стеван Раичковић ; дидактичко-методички текст Оливера Бакочевић ; поговор Слободан Ж. Марковић ; илустровао Владимир Тјапкин. - 4. изд. - Београд : Нолит, 1989. - 64 стр. : илустр. ; $18 \mathrm{~cm}$. - (Лектира за V разред основне школе). - стр. 61-63.

309. Поговор / Слободан Ж. Марковић // Орлови рано лете / Бранко Ћопић ; дидактичко-методички текст Бисерка Јовановић ; поговор Слободан Ж. Марковић . - [4. изд.]. - Београд : Нолит, 1989. - 194 стр. ; 18 cm. - (Лектира за VI разред основне школе / Нолит ; 2). - стр. 189-193.

310. Поговор / Слободан Ж. Марковић // Доживљаји Николетине Бурсаћа / Бранко Ћопић ; поговор Слободан Ж. Марковић ; дидактичко-методички текст Оливера Бакочевић. - [2. изд.]. - Београд : Нолит, 1989. - 169 стр. ; 19 cm. - (Лектира за VIII разред основне школе ; 4). - стр. 162-166.

311. Први дечји листови и књижевност за децу у њима / Слободан Ж. Марковић // Домети. - ISSN 0351-0425. - Год. 16, бр. 57-58 (1989), стр. 105-110.

312. Поговор / Слободан Ж. Марковић // Доживљаји Николетине Бурсаћа / Бранко Ћопић; поговор Слободан Ж. Марковић ; дидактичко-методички текст Оливера Бакочевић. - 3. изд. - Београд : Нолит, 1990. - 169 стр. ; 18 cm. - (Лектира за VIII разред основне школе ; 4). - стр. 162-166.

313. Поговор / Слободан Ж. Марковић // Орлови рано лете / Бранко Ћопић ; дидактичко-методички текст Бисерка Јовановић ; поговор Слободан Ж. Марковић. - [5. изд.]. - Београд : Нолит, 1990. - 194 стр. ; 18 cm. - (Лектира за VI разред основне школе ; 2). - стр. 189-191.

314. Рани Иво Андрић / Слободан Ж. Марковић // Књижевност и језик. - ISSN 0454-0689. - Год. 37, бр. 4 (1990), стр. 313-318.

315. "Србски буквар" Петра Петровића Његоша / Слободан Ж. Марковић. - Научни састанак слависта у Вукове дане 1988 // Научни састанак слависта у Вукове дане. - ISSN 0351-9066. - Књ. 18, св. 2 (1990), стр. 181-186.

316. Petar Pajić: Mašta svih Gavrilovića, Beograd, 1989 / Slobodan Ž. Marković // Detinjstvo. - ISSN 0350-5286. - 16, 1-2 (1990), str. [85]-86. 
317. Razvoj književnosti za decu posle drugog svetskog rata i obrisi i pitanja njene periodizacije / Slobodan Ž. Marković // Detinjstvo. - ISSN 0350-5286. - 16, 1-2 (1990), str. [7]-10.

318. Trag detinjstva - večiti nemir : šezdeset pet godina Đorđa Radišića / Slobodan Ž. Marković. - Izgovoreno u Novom Sadu na stalnoj tribini Zmajevih dečjih igara, 20. novembra 1990 // Detinjstvo. - ISSN 03505286. - God. 16, br. 3/4 (1990), str. 173-176.

319. Treba hteti, treba smeti / Slobodan Ž. Marković. - Prikaz knjige: Fotomonografija Zmajevih dečjih igara 1958-1988, priredio Rade Obrenović // Detinjstvo. - ISSN 0350-5286. - God. 16, br. 1/2 (1990), str. $114-115$.

320. Анто Станичић на мору и приморју детињства / Слободан Ж. Марковић // Немирна : роман / Анто Станичић. - Горњи Милановац : Дечје новине, 1991. - 116 стр. ; 20 cm. - (Библиотека Бели јелен). - стр. 107-[117].

321. Антологија кинеске лирике и Песме старог Јапана, Београд - Горњи Милановац, 1990 / Слободан Ж. Марковић. - 20.07.1991 // Политика. - ISSN 0350-4395. - 88, 27940, стр. 19.

322. Драгољуб Зорић: Живот и књижевно дело Милована Ђ. Глишића, Ваљево, 1991 / Слободан Ж. Марковић // Књижевност и језик. ISSN 0454-0689. - 38, 2 (1991), стр. [239]-241.

323. Из стручних оцена / Слободан Ж. Марковић, Асим Пецо // Са светским славистима / Милош Јевтић. - Горњи Милановац : Дечје новине, 1991. - 505 стр. ; 25 cm. - (Одговори ; 10). - стр. 499-503.

324. Летопис поезије и песничка мисија Десанке Максимовић / Слободан Ж. Марковић. - Расправа // Књижевност и језик. - ISSN 04540689. - 38, 3 (1991), стр. 275-284.

325. Одлике романа са тематиком првог светског рата у српској међуратној књижевности / Слободан Ж. Марковић // Браничево. - ISSN 0006-9140. - год. 37, бр. 5-6 (1991), стр. 57-66.

326. Поговор / Слободан Ж. Марковић // Доживљаји Николетине Бурсаћа / Бранко Ћопић; поговор Слободан Ж. Марковић ; дидактичкометодички текст Оливера Бакочевић. - [3. изд.]. - Београд : Нолит, 1991. - 169 стр. ; 20 cm. - (Лектира за LVII разред основне школе ; 5). - ср. 162-166.

327. Поговор / Слободан Ж. Марковић // Орлови рано лете / Бранко Ћопић ; дидактичко-методички текст Бисерка Јовановић ; поговор Слободан Ж. Марковић. - 6. изд. - Београд : Нолит, 1991. - 194 стр. ; $18 \mathrm{~cm}$. - (Лектира за VI разред основне школе ; 5). - 189-193.

328. Пресек развоја књижевности за децу / Слободан Ж. Марковић. Приказ књ. . - Ново Вуковић „Увод у књижевност за дјецу и омла- 
дину Никшић, 1989 // Књижевност и језик. - ISSN 0454-0689. - 38, 3 (1991), стр. 371-373.

329. Рани Иво Андрић / Слободан Ж. Марковић // Књижевност и језик. - ISSN 0454-0689. - god. 37, br. 4 (1991), стр. [313]-318.

330. Симпозијум: Балкан као обред и метафора. - 1990. - Ћирилицом Учесници у разговору: Света Лукић, Тарик Бугра, Светозар Кољевић, Ксенија Марицки-Гађански, Евангело Масхо, Миодраг Ђукић, Лазар Сиљићи, Нина Живановић, Радослав Златановић, Слободан Ж. Марковић и Халит Трнавци // Развитак. - ISSN 0034-0278. - 30, 4-5, стр. 66-99.

331. Трибина - Тачка ослонца. - 1991. - Ћирилицом Учесници: Слободан Ж. Марковић, Миливоје Павловић, Блажо Перовић и Ратко Божовић // Ток. - ISSN 0351-4978. - 26, 28-29, стр. 52-67.

332. Уметничка слика сеоба за Русију у „Мемоарима” Симеона Пишчевића (1731 - после 1795) / Слободан Ж. Марковић // Реферати и саопштења. 1, Сеобе и изгнанства као тема у југословенским књижевностима / 20. Научни састанак слависта у Вукове дане, Београд, Панчево, Нови Сад, Тршић 11-16. 9. 1990. - Београд : Међународни славистички центар, 1991. - стр. 79-86.

333. Ante Staničić na moru i primorju detinjstva / Slobodan Ž. Marković // Detinjstvo. - ISSN 0350-5286. - god. 17, br. 3-4 (1991), str. [7]-11.

334. Branko V. Radičević: Priče o životinjama, Sarajevo, 1990 / Slobodan Ž. Marković // Detinjstvo. - ISSN 0350-5286. - god. 17, br. 1-2 (1991), str. [92]-93.

335. Radomir Andrić: Kozje grozje, Saraorci, 1990 / Slobodan Ž. Marković // Detinjstvo. - ISSN 0350-5286. - god. 17, br. 3-4 (1991), str. 181-182.

336. Savremena drama za decu i omladinu / Slobodan Ž. Marković. - O knjizi „Pozorišne bajke” Ljubiše Đokića // Detinjstvo. - ISSN 03505286. - god. 17, br. 1-2 (1991), str. [11]-15.

337. Андрићеви предели : (одломак) / Слободан Ж. Марковић. - Додатак: Култура - наука - уметност. - Бр. 651 // Дневник. - ISSN 03507556. - Год. 51, бр. 16511 (14. окт. 1992), стр. 17.

338. Измаштана збиља Драгана Лукића / Слободан Ж. Марковић // Detinjstvo. - ISSN 0350-5286. - god. 18, br. 4 (1992), стр. 5-11.

339. Историјски дух у књижевном делу Иве Андрића / Слободан Ж. Марковић // Књижевност и језик. - ISSN 0454-0689. - Год. 39, бр. 1 (1992), стр. 20-28.

340. Класично и модерно у једном виду поезије Душана Радовића / Слоодан Ж. Марковић// Зборник у част Војислава Ђурића / [главни и одговорни уредник Иво Тартаља]. - Београд : Филолошки факул- 
тет : Филозофски факултет : Институт за књижевност и уметност, 1992. - ISBN 86-80267-05-8. - стр. 345-356.

341. Ново у књижевном стваралаштву за децу девете деценије XX века / Слободан Ж. Марковић // Detinjstvo. - ISSN 0350-5286. - god. 18, br. 1-2 (1992), стр. 16-19.

342. Поговор / Слободан Ж. Марковић // Орлови рано лете / Бранко Ћопић ; дидактичко-методички текст Бисерка Јовановић ; поговор Слободан Ж. Марковић. - [7. изд.]. - Београд : Нолит, 1992. - 194 стр. ; 18 cm. - (Лектира за VI разред основне школе ; 2). - стр. 189-193.

343. Појава и особености српског симболизма = Појавленије и особенности сербского символизма / Слободан Ж. Марковић // Анали Филолошког факултета. - ISSN 0522-8468. - Књ. 19 (1992), стр. 349-361.

344. Косовска традиција у додатку „Српских новина” „Забавнику” / Слободан Ж. Марковић // Наш крај / Сава Стекић, Стеван Симић. - Београд : Завод за уџбенике и наставна средства, 1993. - ISBN 8617-02265-5. - 1стр. 431-437.

345. Проблеми проучавања српске књижевности између два светска рата : питање континуитета и дисконтинуитета / Слободан Ж. Марковић // Књижевност и језик. - ISSN 0454-0689. - Год. 15, бр. 1/4 (1993), стр. 72-78.

346. Српска књижевност између два светска рата / Слободан Ж. Марковић. - 6.10.1993 // Дневник. - ISSN 0350-7556. - 52, 16817, стр. 15.

347. Задужбина Десанка Максимовић / Слободан Ж. Марковић // Даница. - ISSN 0354-4974. - Год. 1 (1994), стр. 311-312.

348. Изворност и лепота детињства у поезији Драгана Лукића / Слободан Ж. Марковић // Ловац Јоца / Драган Лукић ; [избор песама сачинио аутор]. - Смедерево : Смедеревска песничка јесен ; Београд : Санба, 1994. - 109 стр. : илустр. ; 20 цм. - (Библиотека Златни кључић ; књ. 1). - стр. 103-104.

349. Предговор / Слободан Марковић // Задужбина Десанка Максимовић / [уредник Милош Јевтић]. - Београд : Задужбина Десанка Максимовић, 1994. - 37 стр. ; 20 cm. - стр. 3-5.

350. „Предели” у делу Иве Андрића / Слободан Ж. Марковић. - Напомене и библиографске референце уз текст. - Summary: Landscapes in Ivo Andrić's work: стр. 26 // Иво Андрић у своме времену. 1 / Научни састанак слависта у Вукове дане, 22, Београд, Нови Сад, Тршић, 15-20. 9. 1992. - Београд : Међународни славистички центар, 1994. - Стр. 21-26. 
351. Поговор / Слободан Марковић // Вожња по граду / Драган Лукић ; [илустрације Драгана Атанасовић]. - Београд : Српска књижевна задруга, 1994. - 246 стр. : илустр. ; 20 cm. - (Књига за децу и омладину ; 36). - стр. 227-240.

352. Поступак у стварању дела за децу Стевана Раичковића / Слободан Ж. Марковић // Мостови. - ISSN 0350-4263. - год. 26, бр. 133-134 (1994), стр. 30-32.

353. Izmaštana zbilja Dragana Lukića / Slobodan Ž. Marković // Vožnja po gradu / Dragan Lukić; izbor i pogovor Slobodan Ž. Marković. - Beograd : SKZ, 1994. - ISBN 86-379-0493-9. - Str. 227-240.

354. Географски појам као мит у књижевности : Балкан у песничком виђењу Љубомира Мицића и Десанке Максимовић / Слободан Ж. Марковић. - 06.01.1994 // Јединство. - ISSN 0021-5775. - 51, 5, стр. 9.

355. Десанка Максимовић и модерне појаве у српској поезији / Слободан Ж. Марковић // Научни састанак слависта у Вукове дане. - ISSN 0351-9066. - Стр. 151-158.

356. Коментари Милоша Црњанског / Слободан Ж. Марковић // Модерно у прозном дискурсу српске књижевности 20. века. 1 / 23. Научни састанак слависта у Вукове дане, Београд, Нови Сад, Тршић, 14-19 9. 1993. - Београд : Међународни славистички центар, 1995. - Стр. 15-20.

357. Округли сто песничких сусрета „Лазар Вучковић” / Миодраг Петровић... [ет ал.] ; [приредили] Рајко Росић, Јелена Петровић. - 29.09.1995 // Јединство. - ISSN 0021-5775. - 51, 268, стр. 9.

358. Појава, карактер у значај темишварског периодикума Живот 1936. године / Слободан Ж. Марковић //Банатска периодика XIX и XX века / уредиле Весна Матовић, Марија Циндори. - Нови Сад : Матица српска ; Београд : Институт за књижевност и уметност ; Зрењанин : Градска народна библиотека „Жарко Зрењанин”, 1995. - (Серија Историја српске књижевне периодике ; 7). - ISBN 867095-066-9. - (1995), стр. 201-207.

359. Реч - средство, чин и садржај деловања : о Љубомиру Љуби Ненадовићу / Слободан Ж. Марковић. - 20-21.05.1995// Јединство. - ISSN 0021-5775. - 51, 138-139, стр. 9.

360. Траг детињства - вечити немир / Слободан Ж. Марковић // У Змајевом дворишту / Ђорђе Радишић. - Нови Сад : Змајеве дечје игре, 1995. - 27 стр. : илустр. ; 23 ст. - (Библиотека Змај ; 9). - стр. 24-25.

361. Традиционално и модерно у поезији за децу Љубивоја Ршумовића / Слободан Ж. Марковић // Доста је глупоће / Љубивоје Ршумовић. 
- Смедерево : Смедеревска песничка јесен ; Београд : Санба, 1995. - 129 стр. ; 21 cm. - (Библиотека Златни кључић ; књ. 2). - стр. 125-129.

362. Драме Бранислава Нушића у контексту међуратних књижевних појава / Слободан Ж. Марковић // Научни састанак слависта у Вукове дане. - ISSN 0351-9066. - 25/1 (1996), стр. 401-406.

363. Заточеник детињства / Слободан Ж. Марковић // Небо детињства / Мира Алечковић. - Смедерево : Смедеревска песничка јесен ; Београд : Санба, 1996. - 147 стр. : фотограф. ; 21 cm. - (Библиотека Златни кључић ; књ. 3). - стр. 141-145.

364. Стваралачки и људски лик Јована Поповића / Слободан Ж. Марковић // Моја школа „Јован Поповић” : Београд, Инђија, Кикинда, Крагујевац, Крушевац, Лескова, Нови Сад, Обреновац, Сремска Митровица, Сусек, Чока / [уредник Слободан Павићевић]. - Крагујевац : „Јефимија”, 1996. - 180 стр. : илустр. ; 20 cm. - (Библиотека Моја школа). - стр. 11-18.

365. Споменар снова, наде и збиље / Слободан Ж. Марковић // Зборник песама из будућности : 1956 - 1996, листа ученика Основне школе „Доситеј Обрадовић"-Београд / [главни и одговорни уредник Драган Матић]. - Београд : „Diir”, 1996. - 4, 80 стр. ; 21 cm. - стр. 2-3.

366. Трагалачки немири у поезији Васка Попе / Слободан Ж. Марковић // Структура поезије Васка Попе / Ронел Александер ; превела Јесенка Селимовић ; [предговор Слободан Ж. Марковић]. - Београд : Вукова задужбина : Орфелин ; Нови Сад : Матица српска, 1996. - 147 стр. : илустр. ; 24 cm. - (Студије о Србима ; св. 7). - стр. 5-8.

367. Три љубави Живана Живковића / Слободан Ж. Марковић // Detinjstvo. - ISSN 0350-5286. - god. 22, br. 4 (1996), стр. 4-8.

368. Библијски мотиви у поезији Растка Петровића / Слободан Ж. Марковић // Српска књижевност и Свето писмо / 26. научни састанак слависта у Вукове дане, Београд, Манасија, 9-14. 9. [1996.]. Београд : Међународни славистички центар, 1997. - стр. 467-473.

369. Вече посвећено Миловану Глишићу / Олга Марковић, Слободан Ж. Марковић, Зоран Т. Јовановић // Teatron. - ISSN 0351-7500. - Год. 22, бр. 101 (1997), стр. 72-78.

370. Др Живан Живковић (28. IV 1952. Нови Карловци - 16. XII 1996. Београд) / Слободан Ж. Марковић // Књижевност и језик. - ISSN 0454-0689. - Год. 45, бр. 1 (1997), стр. 157-159.

371. Поетска казивања деци Добрице Ерића / Слободан Ж. Марковић // Чудесни свитац : изабране песме за младе / Добрица Ерић. - Смедерево : Смедеревска песничка јесен, 1997. - 139 стр. ; 21 cm. (Библиотека Златни кључић ; књ. 4). - стр. 131-137. 
372. Предсловје : корени : развој књижевности за децу код Срба / Слободан Ж. Марковић // Азбучник благогласности : (писци за децу - од Захарије Орфелина до наших дана) / приредио Светозар Малешев. - Нови Сад : Змајеве дечје игре, 1997. - 80 стр. : илустр. ; 23 х 21 cm. - стр. 3-8.

373. Приређивање песама за децу у целокупним делима Десанке Максимовић / Слободан Ж. Марковић // Приређивање издања целокупних дела Десанке Максимовић / Десанкини мајски разговори, Београд, Ваљево, Бранковина, 14, 15. и 16. маја 1996. - Београд : Задужбина „Десанка Максимовић”, 1997. - (Десанкини мајски разговори). - (1997), стр. 63-69.

374. Свјетлост и сјенке : типологија приповедачке прозе међуратних писаца из Црне Горе / Слободан Ж. Марковић // Побједа. - ISSN 0350-4379. - 53, 11322 (21.06.1997), стр. 11.

375. Трајање идеја и искуства надреализма у књижевности / Слободан Ж. Марковић/ / Зборник Матице српске за славистику. - ISSN 0352-5007. - 53 (1997), стр. 163-169.

376. Глас предака у поезији Десанке Максимовић / Слободан Ж. Марковић // Научни састанак слависта у Вукове дане. - ISSN 0351-9066. - 28/1 (1998), стр. 217-225.

377. Двадесети век - век песникиње / Слободан Ж. Марковић. - О поезији Десанке Максимовић // Новине Београдског читалишта. - ISSN 0354-2041. - 8, 27 (1998), стр. 6.

378. Значење појма бајке у делу Десанке Максимовић / Слободан Ж. Марковић // Рецепција дела Десанке Максимовић / приредио Слободан Ж. Марковић. - Београд : Задужбина „Десанка Максимовић”, 1998. - (Десанкини мајски разговори ; књ. 6). - (1998), стр. 87-98.

379. Јован Јовановић Змај и књига за народ издавачке књижаре Браћа Јовановић у Панчеву / Слободан Ж. Марковић // Свеске. - ISSN 0353-5525. - Јул (1998), стр. 59-61.

380. Поетска виђења Радована Зоговића у периоду између два светска рата / Слободан Ж. Марковић // Радован Зоговић - живот и стваралаштво / уредник Ново Вуковић. - Подгорица : Црногорска академија наука и умјетности, 1998. - (Научни скупови ; књ. 51. Одјељење умјетности ; књ. 16). - ISBN 86-7215-102-X. - 5116 (1998), стр. 45-53.

381. Постојаност детињства у песмама Пере Зупца / Слободан Ж. Марковић // Лет изнад детињства / Перо Зубац. - Смедерево : МФП Смедеревска песничка јесен ; Београд : Санба, 1998. - 175 стр. : илустр. ; 21 cm. - (Библиотека Златни кључић ; књ. 5). - стр. 166173. 
382. Развој књижевности за децу после Другог светског рата и питање њене периодизације / Слободан Ж. Марковић ; одабрао Перо Зубац. - Надређени ств. насл.: Ја те чекам, чекам с нестрпљењем // Алманах. - ISSN 1450-6165. - 1998, стр. 253.

383. Речи дарујуће лепоте / Слободан Ж. Марковић // Са страница „Детињства" / Живан Живковић. - Нови Сад : Змајеве дечје игре, 1998. - 82 стр. ; 23 cm. - (Библиотека Змај ; књ. 10). - стр. 81-82.

384. Сећање на детињство као вид аутобиографског у приповедној прози Бранка Ћопића / Слободан Ж. Марковић // Српска аутобиографска књижевност / 27 научни састанак слависта у Вукове дане, Београд, Нови Сад, Манасија, 9-13. 9. 1997. - Београд : Међународни славистички центар, 1998. - (1998), Стр. 374-377.

385. Симболика наслова „На прагу миленијума” Танасија Младеновића / Слободан Ж. Марковић // Дневник. - ISSN 0350-7556. - 57, 18520 (19.08.1998), стр. 15.

386. Століття Десанки Максимович : 1898-1998 / Слободан Ж. Марковић ; [переклад Марія Багрій]. - ауторова слика. - Слика Д. Максимовић // Українс'ке слово. - ISSN 0354-9208. - Рік 3, ч. 5 (1998), стр. 48-51.

387. Reč na otvaranju Četrnaestoga kongresa saveza slavističkih društava Jugoslavije, u Budvi, 16.10.1997. / Slobodan Ž. Marković // Србистика. - ISSN 1450-670X. - 1, 1 (1998), str. 69-76.

388. Алекса Шантић и модерна / Слободан Ж. Марковић. - Белешке // Српски језик. - ISSN 0354-9259. - Год. 4, бр. 1/2 (1999), стр. 759765.

389. Балкан као мотив, инспирација и песничко виђење у поезији Десанке Максимовић / Слободан Ж. Марковић // Међај. - ISSN 03515451. - 43 (1999), стр. 11-20.

390. Значење и употреба речи „Интелектуалац” и „Интелигенција” / Слободан Ж. Марковић // Липар. - ISSN 1450-8338. - 1, 1 (1999), стр. 18-19.

391. Јован Скерлић и нова српска књижевност / Слободан Ж. Марковић // Студије и критике / Јован Скерлић. - Београд : Завод за уџбенике и наставна средства, 1999. - (Библиотека Избор). - ISBN 86-1704905-7. - Стр. 7-13.

392. Књижевност за децу не може се изучавати изван књижевности / Слободан Ж. Марковић // Детињство. - ISSN 0350-5286. - Год. 25, бр. 4 (1999), стр. 11-17.

393. Књижевност за децу у Књижевном северу / Слободан Ж. Марковић. - Summary // Књижевни север / уредила Марија Циндори. - Нови Сад : Матица српска : Институт за књижевност и уметност, 1999. 
- (Серија Историја српске књижевне периодике ; 10). - 10 (1999), стр. 90-95.

394. Мит у сатиричном приповедачком поступку Радоја Домановића / Слободан Ж. Марковић // Књижевно дело Радоја Домановића - ново читање / [уредио Мирољуб Стојановић. - Ниш : Центар за научна истраживања САНУ и Универзитета : Студијска група за српски језик и књижевност Филозофског факултета, 1999. - ISBN 867379-056-5. - (1999), стр. 253-260.

395. Од погледа до пољупца / Слободан Ж. Марковић // Јабука од злата : стихови за младе / Слободан Станишић. - Смедерево : Смедеревска песничка јесен ; Београд : Санба, 1999. - (Библиотека Златни кључић ; књ. 6). - стр. 157-165.

396. Рат речима / Слободан Ж. Марковић. - Ћирилицом. - О теми „Књижевност-дете-рат" // Детињство. - ISSN 0350-5286. - 25, 2/3 (1999), стр. 5-8.

397. Тема прошлости у поезији Десанке Максимовић / Слободан Ж. Марковић. - Напомене уз текст. - Summary // Поезија и поетика Десанке Максимовић / [уредници Милош Ђорђевић, Жељко Ћупић. - Приштина : Институт за српску културу : Друштво књижевника Косова и Метохије : Културна манифестација „Глигорије Глиша Елезовић" ; Београд : Стручна књига, 1999. - (Библиотека У свету књижевног дела ; књ. 3). - стр. 25-32.

398. Тема прошлости у поезији Десанке Максимовић / Слободан Ж. Марковић. - Белешке. - Summary // Баштина. - ISSN 0353-9008. - Књ. 9/10 (1998/99), стр. 25-32.

399. Алекса Шантић и модерна / Слободан Ж. Марковић . - Ћирилица. - Summary // Алекса Шантић / уредник Радован Вучковић. - Бања Лука ; Српско Сарајево : Академија наука и умјетности Републике Српске, 2000. - (Зборници и монографије ; књ. 3. Одјељење књижевности и умјетности ; књ. 3). - ISBN 86-83255-05-0. - (2000), стр. 104-110.

400. Бајковита љубав и необичан мегдан : Горан Бабић: Облаци, Београд, 2000 / Слободан Ж. Марковић // Детињство. - ISSN 0350-5286. Год. 26, бр. 3/4 (2000), стр. 74.

401. Вишестрани књижевни посланик : Христо Георгијевски (19432000) / Слободан Ж. Марковић // Детињство. - ISSN 0350-5286. - Год. 26, бр. 3/4 (2000), стр. 87-91.

402. Жанрови у модерној прози за децу / Слободан Ж. Марковић // Развој прозних врста у српској књижевности / 29. научни састанак слависта у Вукове дане, Београд, Нови Сад, 14-19. 9. 1999. - Београд : Међународни славистички центар, 2000. - стр. 335-340. 
403. Историја и сећање - поетски ослонци Драгана Колунџије / Слободан Ж. Марковић // Липар. - ISSN 1450-8338. - 2, 4 (2000), стр. 27-28.

404. Поетски лук љубави и сете Ђорђа Радишића / Слободан Ж. Марковић // Чаролија зрења / Ђорђе Радишић. - Смедерево : Смедеревска песничка јесен, 2000. - (Библиотека златни кључић ; књ. 7). - стр. 151-154.

405. Пред јубилејом друштва за српски језик и књижевност / Слободан Ж. Марковић // Књижевност и језик. - ISSN 0454-0689. - Год. 47, бр. 3/4 (2000), стр. 1-13.

406. Христо Георгијевски : (Куманово, 24. 10. 1943 - Београд, 3. 6. 2000) / Слободан Ж. Марковић // Зборник Матице српске за књижевност и језик. - ISSN 0543-1220. - 48, 2-3 (2000), стр. 625-628.

407. Беседе о библиотекарству и књизи / Слободан Ж. Марковић // Липар. - ISSN 1450-8338. - Год. 3, бр. 7 (2001), стр. 33-34.

408. Историјски романи Михајла Лалића „Свадба” и Оскара Давича „Песма” / Слободан Ж. Марковић // Књижевност и историја. 4 / [уредио Мирољуб Стојановић. - Ниш : Центар за научна истраживања САНУ и Универзитета : Студијска група за српски језик и књижевност Филозофског факултета ; [Београд] : Славистичко друштво Србије, 2001. - ISBN 86-7025-303-8. - Стр. 73-79.

409. О едицији Студије о књижевном делу Десанке Максимовић / Слободан Ж. Марковић // Библиографија дела Десанке Максимовић : 1920-1971 / Љубица Ђорђевић. - Београд : Задужбина Десанке Максимовић : Народна библиотека Србије : Филолошки факултет, Центар за источну Азију : Мрљеш, 2001. - (Студије о књижевном делу Десанке Максимовић ; књ. 1). - ISBN 86-7035-085-8. - стр. 7-8.

410. Српска прича за децу / Слободан Ж. Марковић. - илустр // Липар. - ISSN 1450-8338. - Год. 3, бр. 9 (2001), стр. 22-24.

411. Типологија приповедачке прозе међуратних писаца из Црне Горе / Слободан Ж. Марковић // Гласник Одјељења умјетности. - ISSN 0350-5480. - Књ. 19 (2001), стр. 51-56.

412. Чежња за завичајем / Слободан Ж. Марковић // Дневник. - ISSN 0350-7556. - Год. 78, бр. 19708 (19.12.2001), стр. 20.

413. Колунџијино певање, родољубиво и љубавно : (одломци) / Драган М. Јеремић, Михаило Лалић, Скендер Куленовић, Младен Ољача, Слободан Ж. Марковић, Чедомир Мирковић, Бранислав Петровић, Ранко Рисојевић, Божо Вукадиновић, Владета Јеротић, Миливоје Марковић, Слободан Ракитић, Васа Павковић, Флорика Штефан, Стеван Тонтић, Петар Гудељ, Богдан А. Поповић // Век у ратовима 
и у љубави / Драган Колунџија. - Рума : Српска књига, 2002. - 245 стр. : ауторова слика ; 22 cm. - ISBN -7564-045-5. - Стр. 227-235: Колунџијино певање, родољубиво и љубавно : (одломци) / Драган М. Јеремић, Михаило Лалић, Скендер Куленовић, Младен Ољача, Слободан Ж. Марковић, Чедомир Мирковић, Бранислав Петровић, Ранко Рисојевић, Божо Вукадиновић, Владета Јеротић, Миливоје Марковић, Слободан Ракитић, Васа Павковић, Флорика Штефан, Стеван Тонтић, Петар Гудељ, Богдан А. Поповић.

414. Покрет социјалне књижевности / Слободан Ж. Марковић. - Напомене и библиографске референце уз текст // Епохе и стилови у српској књижевности / приредили Малиша Станојевић, Слободан Лазаревић. - Београд : Филолошки факултет ; Крагујевац : Нова светлост, 2002. - (Библиотека Лицеј ; књ. 9). - ISBN 86-7247-014-1. - Стр. 495-518.

415. Свет детињства у поезији Мирослава Антића / Слободан Ж. Марковић // Детињство. - ISSN 0350-5286. - Год. 28, бр. 1/2 (2002), стр. 49-53.

416. Однос песника средином XX века према фоклору : (Васко Попа, Блаже Конески, Валери Петров) / Слободан Ж. Марковић. - Белешке уз текст // Зборник Матице српске за славистику. - ISSN 03525007. - 63 (2003), стр. 149-157.

417. Бајковити свет : (Гроздана Олујић: „Седефна ружа и друге бајке”, Загреб, 1979) / Слободан Ж. Марковић // Браничево. - ISSN 00069140. - Год. 50, бр. 2 (април/јун 2004), стр. 170-171.

418. Песник и родни крај / Слободан Ж. Марковић // Десанка Максимовић у завичају : [фотомонографија] / Драгиша Меденица. - Београд : Задужбина Десанке Максимовић : Народна библиотека Србије ; Ваљево : Установа за културу младих Омладински центар, 2004. - (Студије о књижевном делу Десанке Максимовић ; књ. 7). - ISBN 86-82377-21-7. - Стр. 5-9.

419. Почеци рада на историји српске књижевности за децу / Слободан Ж. Марковић. - Кор. насл.: Историја и историчари српске књижевности. - Напомене и библиографске референце уз текст // Научни састанак слависта у Вукове дане. - ISSN 0351-9066. - 32/2 (2004), стр. [365]-374.

420. Синкретизам књижевних родова у поемама за децу / Слободан Ж. Марковић. - Напомене и библиографске референце уз текст // Научни састанак слависта у Вукове дане. - ISSN 0351-9066. - 33/2 (2004), стр. [193]-197.

421. Синкретизам књижевних родова у поемама за децу / Слободан Ж. Марковић. - Белешке // Браничево. - ISSN 0006-9140. - Год. 50, бр. 1 (2004), стр. 227-232. 
422. Вишестрани књижевни посленик / Слободан Ж. Марковић // Роман у српској књижевности за децу и младе / Христо Георгијевски. - Нови Сад : Змајеве дечје игре, 2005. - 173 стр. ; 22 cm. - (Библиотека Змај ; књ. 15). - ISBN 86-81501-23-2. - Стр. 155-159.

423. Др Живан Живковић - кратак, а богат живот / Слободан Ж. Марковић // Годишњак. - ISSN 1820-5305. - Год. 2 (2005), стр. 9-12.

424. Песничка зора Зорке Кнежевић / Слободан Ж. Марковић // Пингвин и маслачак : песме и колажи / Зорка Кнежевић. - Рума : Српска књига, 2005. - (Библиотека Посебна издања / Српска књига. Српски писци). - ISBN 86-7564-318-7. - Стр. 84-85.

425. Разнородност и богатство стваралаштва Христе Георгијевског / Слободан Ж. Марковић // Годишњак. - ISSN 1820-5305. - Год. 1, бр. 1 (2005), стр. 7-13.

426. Изводи из рецензија / Слободан Ж. Марковић, Тихомир Петровић, Спасоје Граховац // Збирке за децу Стевана В. Поповића / [приредила] Мара Кнежевић. - Сомбор : Педагошки факултет, 2006. - (Библиотека Уџбеници и приручници / Педагошки факултет ; књ. бр. 123). - ISBN 86-83097-57-9. - Стр. 201.

427. Књига за децу данас / Слободан Ж. Марковић. - Сажетак; Summary // Деца и библиотеке / уредник Александра Вранеш. - Београд : Филолошки факултет Универзитета : Библиотекарско друштво Србије, 2006. - ISBN 86-86419-10-0. - Стр. 31-35.

428. Над одром Драгана Лукића / Слободан Ж. Марковић // Детињство. - ISSN 0350-5286. - Год. 32, бр. 1 (2006), стр. 3-4.

429. [У поезији и лирској прози...] / Слободан Ж. Марковић. - Одломак из чланка „Измаштана збиља Драгана Лукића” у часопису Детињство, XVIII/4, 1992 // Детињство. -ISSN 0350-5286. - Год. 32, бр. 1 (2006), стр. 105.

430. Хумор у делима српских писаца у трећој и четвртој деценији двадесетога века / Слободан Ж. Марковић // Реч - морфолошки, синтаксички, семантички и формални аспекти у српском језику ; Хумористичка и сатирична традиција у српској књижевности. 2 / 35. Научни састанак слависта у Вукове дане, Београд 7-10. 9. 2005. - Београд : Међународни славистички центар, 2006. - (МСЦ, ISSN 0351-9066). - ISBN 86-86419-16-X. - 35, 2 (2006), стр. 279-285.

431. Записи о књижевности за децу : писци и дела. 4 / Слободан Ж. Марковић. - Београд : Београдска књига, 2007. - 206 стр. ; 20 cm. - (Библиотека Путеви сазнања / [Београдска књига] ; књ. 5). - Напомене и библиографске референце уз текст. - ISBN 978-86-7590-176-1.

432. Национално и патриотско у поезији за децу некад и сад / Слободан Ж. Марковић. - Summary // Детињство. - ISSN 0350-5286. - Год. 33, бр. 3/4 (2007), стр. 3-11. 
433. Стварност у поетици покрета социјалне књижевности београдског круга / Слободан Ж. Марковић. - Напомене и библиографске референце уз текст // Научни састанак слависта у Вукове дане. - ISSN 0351-9066. - 36/2 (2007), стр. [297]-302.

434. Љубисав-Љуба Станојевић фрагменти сећања / Слободан Ж. Марковић // Проф. др Љубисав Љуба Станојевић - живот и дело / [организатор] Центар за научна истраживања САНУ и Универзитета у Нишу, Одсек за књижевност. - Ниш : Центар за научна истраживања САНУ и Универзитета, 2008. - (Библиотека Књижевни и културни живот на југоистоку Србије у ХИХ и ХХ веку ; књ. 10). - ISBN 978-86-7746-138-6. - Стр. [19]-25.

435. Модерни традиционализам у поезији Десанке Максимовић / Слободан Ж. Марковић. - Напомене и библиографске референце уз текст. - Summary // Традиционално и модерно у стваралаштву Десанке Максимовић / Десанкини мајски разговори, Бања Лука, 1820. мај 2007. - Београд : Задужбина „Десанке Максимовић” ; Бања Лука : Филозофски факултет, 2008. - (Десанкини мајски разговори ; књ. 25). - ISBN 978-86-82377-28-3. - Стр. 5-14.

436. Оснивање Вукове задужбине / Слободан Ж. Марковић. - илустр // Даница. - ISSN 0354-4974. - Год. 15 (2008), стр. 73-91.

437. Родни крај / Слободан Ж. Марковић // Мионичка општина : завичај војводе Живојина Мишића / Милорад Радојчић. - Београд : Фондација војвода Живојин Мишић, 2008. - ISBN 978-86-909017-1-5. - Стр. 7-11.

438. Српска књижевност средином 20. века - размеђе традиционалног, социјалистичког и модерног / Слободан Ж. Марковић. - Напомене и библиографске референце уз текст // Зборник Матице српске за славистику. - ISSN 0352-5007. - Бр. 73 (2008), стр. [259]-266.

439. Историјски дух у књижевном делу Иве Андрића / Слободан Ж. Марковић. - Напомене уз текст // Прилози језичком и књижевном образовању / приредила Босиљка Милић. - Београд : Друштво за српски језик и књижевност Србије, 2008. - (Зборник ; 1). - ISBN 978-86-84885-33-5. - Стр. 109-116.

440. Савремено дете и књижевни садржаји за младе / Слободан Ж. Марковић. - Резиме; Summary // Детињство. - ISSN 0350-5286. - Год. 35, бр. 3 (2009), стр. 5-10.

441. Друштво за српски језик и књижевност и часопис Наш језик / Слободан Ж. Марковић // Наш језик. - ISSN 0027-8084. - Књ. 41, св. 3/4 (2010), стр. 107-111.

442. Друштво за српски језик и књижевност и часопис Наш језик / Слободан Ж. Марковић. - Напомене и библиографске референце уз 
текст. - Апстракт ; Резиме // Наш језик. - ISSN 0027-8084. - Књ. 41, св. 3/4 (2010), стр. 107-111.

443. Избор из критика о књижевном делу др Милутина Пашића / Драгољуб Зорић ... [и др.]. - Остали аутори: Драгољуб Зорић, Милијан Деспотовић, Слободан Ж. Марковић, Светозар Радоњић-Рас, Миодраг Игњатовић, Мирко Иконић, Милутин Пашић, Ратомир Цвијетић // Свитак. - ISSN 0354-7329. - Год. 17, бр. 61/62 (2010), стр. $8-12$.

444. Поговор / Слободан Ж. Марковић // Сусрети у књижевности двају блиских народа : огледи из компаратистике, балканистике и југославистике / Илија Конев. - 1. изд. - Београд : Завод за уџбенике : Вукова задужбина ; Нови Сад : Матица српска, 2010. - (Студије о Србима ; књ. 19). - ISBN 978-86-17-16298-4. - стр. 182-185.

445. Родољубље у српској поезији за децу / Слободан Ж. Марковић. Напомене и библиографске референце уз текст. - Summary // Фолклор, поетика, књижевна периодика / уредник Станиша Тутњевић. - Београд : Институт за књижевност и уметност, 2010. - (Посебно издање ; књ. 33). - ISBN 978-86-7095-162-4. - Стр. 695-705.

446. Скромност, предузимљивост и упорност Срећка Јовановића / Слободан Ж. Марковић // Са књигом у руци : разговори са Срећком Јовановићем / [разговор водио] Милош Јевтић. - Горњи Милановац : Библиотека „Браћа Настасијевић” : Музеј рудничко-таковског краја, 2010. - (Колекција Одговори / [Милош Јевтић] ; књ. 182). - ISBN 978-86-83847-31-0. - Стр. 5-8.

447. Узајамно деловање књижевности и културе у социјалној литератури / Слободан Ж. Марковић. - Напомене и библиографске референце уз текст // Књижевност и култура. 2 / 39. научни састанак слависта у Вукове дане, Београд, 9-12. IX 2009. - Београд : Међународни славистички центар, 2010. - (МСЦ, ISSN 0351-9066). - ISBN 97886-86419-91-0. - Стр. 435-441.

448. Песник и родни крај / Слободан Ж. Марковић // Ваљево - град и околина : време за незаборав : фотомонографија Драгише Меденице. - Ваљево : Д. Меденица, 2011. - Стр. 92-93. - ISBN 978-86914801-0-3.

449. Сарадња српских и немачких писаца у трећој деценији двадесетог века / Слободан Ж. Марковић. - Напомене и библиографске референце уз текст // 40. научни састанак слависта у Вукове дане, Београд, 8-11. IX 2010, Београд. 2, Српска књижевност и европска књижевност. - Београд : Филолошки факултет, Међународни славистички центар, 2011. - (МСЦ, ISSN 0351-9066). - ISBN 978-866153-039-5. - 40/2 (2011), стр. 269-278. 
450. Књижевност за децу предшколског узраста : (на примеру две песме Јована Јовановића Змаја и Дечија соба Десанке Максимовић) / Слободан Ж. Марковић // Књижевност за децу и њена улога у васпитању и образовању деце предшколског узраста / [главни и одговорни уредник Сунчица Денић]. - Врање : Учитељски факултет, 2012. - ISBN 978-86-82695-92-9. - Стр. 13-18.

451. Македонски језик и књижевност на Филолошком факултету Универзитета у Београду (шест и по деценија рада) / Слободан Ж. Марковић. - Апстракт // Књижевност и језик. - ISSN 0454-0689. - Год. 59, бр. 3/4 (2012), стр. 225-229.

452. Мисао и дело Доситеја Обрадовића су симбол и инспирација / Слободан Ж. Марковић // Идућ' учи, у векове гледа : награђени радови на конкурсу за ученике средњих школа : 2009-2012. / [приредила Марија Бишоф]. - Београд : Задужбина „Доситеј Обрадовић”, 2012. - (Едиција Млади ствараоци ; књ. 2). - Стр. 7-9. - ISBN 978-8687583-11-5.

453. Десанка Максимовић - посредник у књижевностима и културама словенских народа / Слободан Ж. Марковић // Зборник Матице српске за славистику. - ISSN 0352-5007. - бр. 83 (2013), стр. 109-117.

454. Научно издање целокупних дела Десанке Максимовић / Слободан Ж. Марковић // Књижевна историја. - ISSN 0350-6428. - Год. 45, бр. 149 (2013), стр. 295-301.

455. Слободан Ж. Марковић / [разговор водио] Милош Јевтић. - Разговор са Слободаном Ж. Марковићем вођен је у Београду јуна 1984. Године // Са домаћим славистима. Књ. 2 / Милош Јевтић. - Београд : Завод за уџбенике, 2013. - (Колекција Одговори ; књ. 191). - ISBN 978-86-17-18293-7. - Стр. [11]-30.

456. Човеколика фантастика : битна особина поетског света за децу Десанке Максимовић / Слободан Ж. Марковић. - Библиографија: стр. 26. - Резиме // Књижевност за децу и њена улога у васпитању и образовању деце школског узраста / [главни и одговорни уредник Сунчица Денић]. - Врање : Учитељски факултет, 2013. - ISBN 97886-6301-005-5. - Стр. 20-27.

457. О пријатељству, песникињи и времену / Слободан Ж. Марковић // Моја Десанка / Љубиша Ђидић. - Смедерево : Арка, 2015. - (Библиотека Арка). - ISBN 978-86-7610-168-9, Стр. 7-11. 